\title{
المسئولية الاجتماعية للرائدات الريفيات بالوحدات الصحية وتنمية الوعي لدى المرأة الريفية بمخاطر جائحة فيروس كورونا
}

\author{
دكتورة/ نورا أهين عبد الرحمن إبراهيم شحاتة \\ مدرس بقسم تنظيم المجتمع \\ المعهة العالي للخدمة الاجتماعية بالمنصورة
}




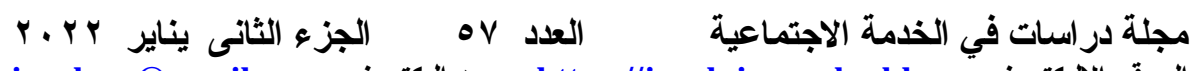

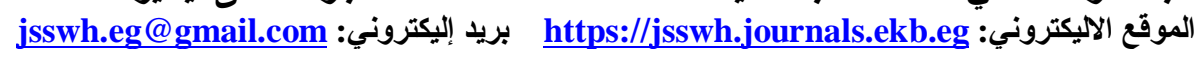


يصف هذا البحث المسئولية الاجتماعية للرائدات الريفيات بالوحدات الصحية

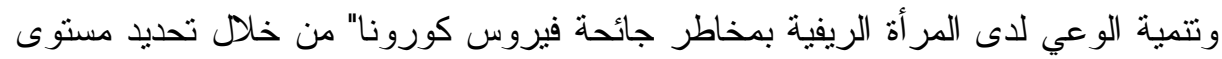

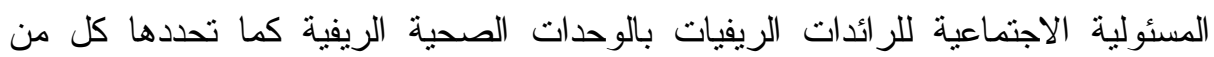

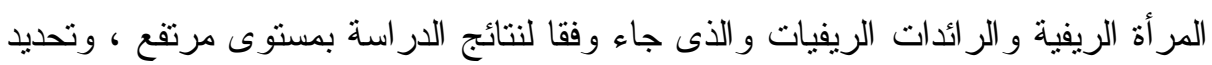

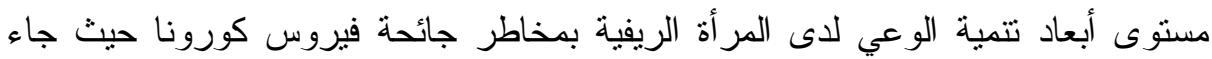

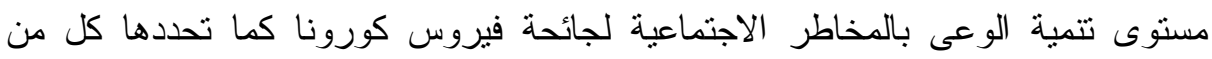

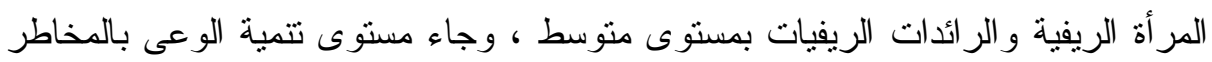

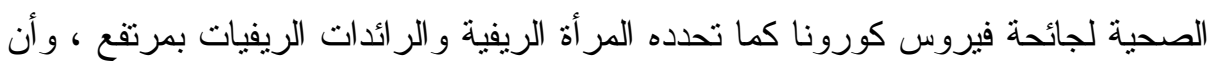

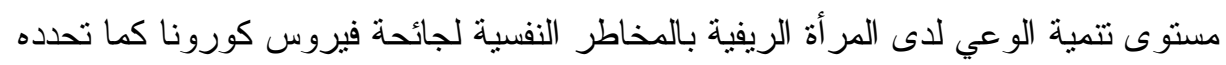

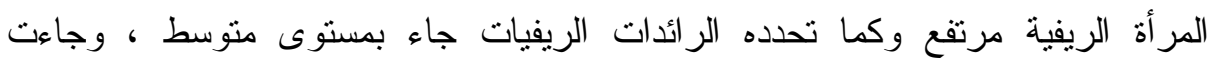

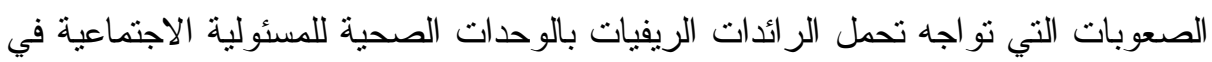

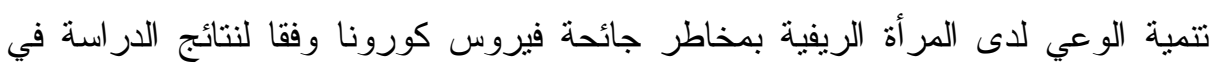

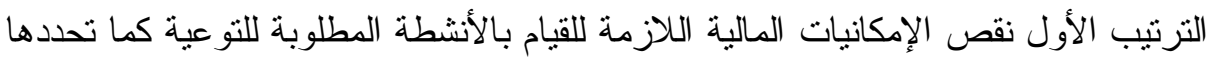

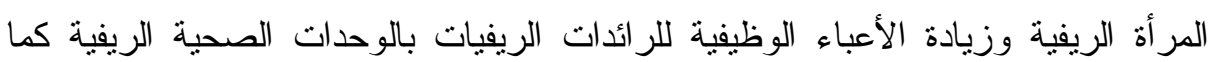

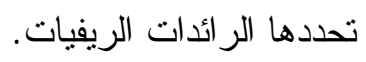

الكلمات الدالة: المسئولية الاجتماعية - الرائدات الريفيات - الوحدات الصحية - الوعي المر أة الريفية - جائحة فيروس كورونا.

\section{.Abstract:}

This research describes the social responsibility of rural women leaders in health units and the development of awareness among rural women of the risks of the Corona virus pandemic "by determining the level of social responsibility of rural women pioneers in rural health units as determined by both rural women and rural pioneers, which came according to the results of the study at a high level, and determining the level of dimensions of awareness development Rural women have the risks of the coronavirus pandemic, where the level of development of awareness of the social risks of the coronavirus pandemic, as determined by both rural women and rural pioneers, is at a medium level, and the level of development of awareness of the health risks of the coronavirus pandemic, as determined by rural women and rural pioneers, is high And that the level of developing awareness among rural women of the psychological risks of the 
coronavirus pandemic as determined by rural women is high and as determined by the rural pioneers came to an average level, and the difficulties faced by the rural pioneers in the health units of social responsibility came in developing awareness among rural women of the dangers of the Corona virus pandemic, according to the results of the study in the first order of the lack of financial capabilities necessary to carry out of the activities required to raise awareness as determined by rural women and to increase the job burdens of rural women leaders in rural health units as determined by rural women leaders.

Keywords: social responsibility - rural pioneers - health units awareness - rural women - corona virus pandemic.

أولاً: مدخل لمشكلة الاراسة: - مأس

يعد موضوع المسئولية الاجتماعية قضية تربوية واجتماعية وأخلاقية ودينية

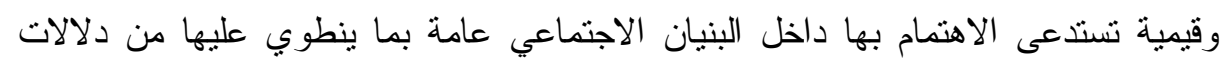

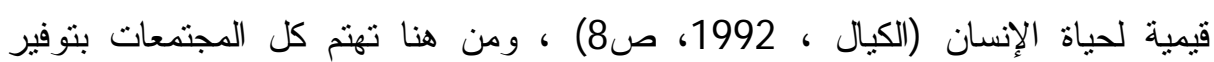
مجموعة من الخدمات التي تقدم للمواطنين بقصد تزويدهم بنوع من الخبرة الجماعية تتيح لهم فرص النمو السليم (سعد ، 1996، صنمات 111)، والتي تساعد على تتمبة المسئولية

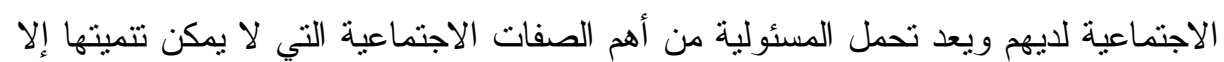

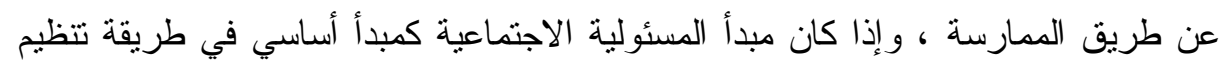
المجتمع فإنه يركز على الربط بين مفهومين أساسين هما الحقوق و الواجبات فهي مسئولية

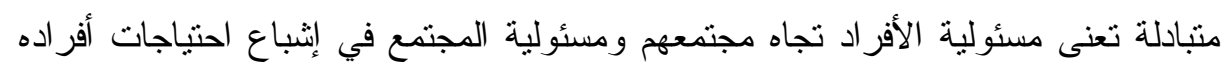

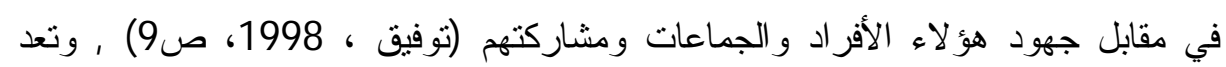

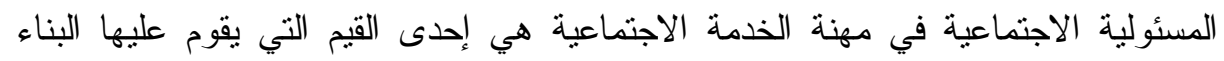

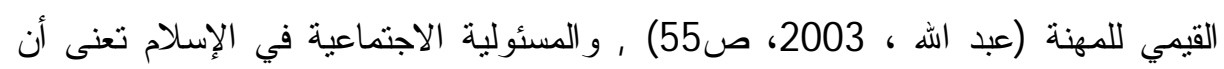
الفرد مسئول بصفته الثخصية عن صالحه وصالح المجتمع الذى يعيش فيه وسلامة هذا لإنها

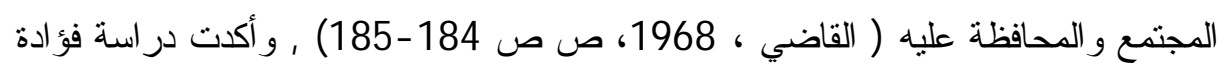
Fukuda (2002) أن هناك أبعاد لتحقيق تتمية المسئولية الاجتماعية ومنها إعداد وتأهيل

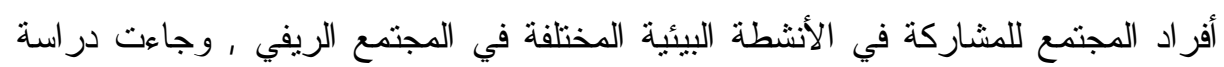

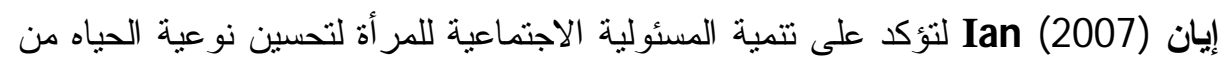

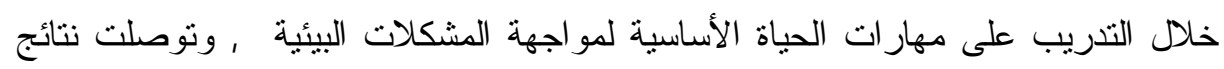
دراسة ميتف Mitev (2019) إلى أهمية أنشطة المسئولية الاجتماعية النتاركية في لئية 


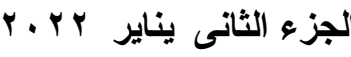

OV العدد

مجلة در اسات في الخدمة الاجتماعية

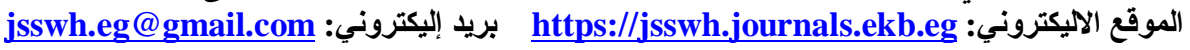

تشجيع و لاء موظفي المستشفيات و العملاء بشكل مباشر , وتوصلت دراسة محمد (2020) إلى مجموعة من النتائج أهمها أن المسئولية الاجتماعية للشباب الجامعي تمنلت في الالتز ام بالآداب العامة والأخلاق الدينية في اجتتاب الأشياء التي تسبب أضرار صحية ، وتخصيص التص التص أدوات للنظافة الثخصية ، وتوعية أفراد الأسرة بأهمية العزل المنزلي عند الثعور بأعر اض مرض معدى , وتعنبر الرائدة الريفية حلقة الوصل بين المؤسسات الحكومية و الأهالي في القرية وهى تمثل قيادة طبيعية يتم اختيار ها بعناية وتدريبها حتى تستطيع أداء دور ها في التوعية و التمهيد لبعض البر امج القومية التي تتبناها الدولة كأساس لتطوير الحياه في المجتمع المحلى ، وتعمل الر ائدة بالتوعية في شتى المجالات المرتبطة بالمشروعات القومية منل تتظيم الأسرة ، و الرعاية الصحية ، و الأندية النسائية الريفية إلخ (وزارة

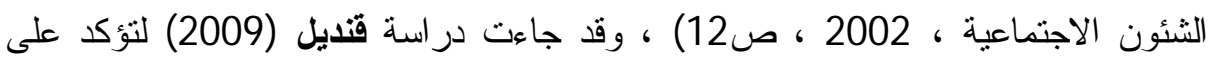
أهمية تدريب الرائدات الريفيات على مجموعة من المعارف و المهارات الني تمكنها من توصيل المعلومات إلى المرأة في الريف و إقناعها بهذه المعلومات ، كما أن الرائدات الريفيات في حاجة إلى التوعية الثقافية و الاجتماعية و الدينية المناسبة كقيادات نسائية ، حيث يكون لديهن مصدر يساعدهن على أداء مسئولياتهم الاجتماعية ودور هن نحو أهالي القرية ( حماد ، 1994 ، ص33)، وقد جاءت دراسة عبد الله ( 2021) و التي استهدفت بناء القدرات المهارية للرائدات الريفيات منّ مهارة الاتصال ، ومهارة استثارة السيدات للمشاركة ، ومهارة إقامة علاقات اجتماعية ، وتمثل المرأة الريفية تلث سكان مصر وهى تو اجه مشكلات كثثرة تعوق حركتها وتضعف كفاءتها كالتخلف وسوء الحالة الصحية، نتيجة الإصابة بالأمر اض المستوطنة و إذا كان الحديث يدور حول المر أة الريفية التي تسعى ونى إلى أن تأخذ مكانها الآئق جنباً إلى جنب مع الرجل من أجل تتمية المجتمع فمن هنا كانت العناية بالمر أة الريفية وتوعيتها و إعدادها الإعداد الصحيح ومساعدتها على القيام بواجباتها من الأمور بالغة الأهمية التي تعمل على رفع مستوى معيثتها اقتصاديا و اجتماعيا وزيادة الوعى بحقوقها العامة ومن أولويات حقوق المرأة الريفية هي الاهتمام بصحتها وحمايتها

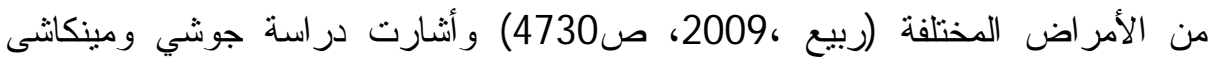
Joshi \& Meenakshi (4004) تستهدف المر أة في المناطق الريفية و التي تشمل برامج التوعية و التذريب وبر امج نوليد الاخل وبر امج لبناء القدرات و التي تستهدف نمكين المرأة في المناطق الريفية و أظهرت نتائج الدراسة إلى أن هذه المشروعات و البرامج أدت إلى زيادة الوعى بثأن أدوار 
ومسئوليات المر أة مما أدى إلى زيادة مشاركة المرأة اقتصاديا واجتماعيا، ومن أولويات

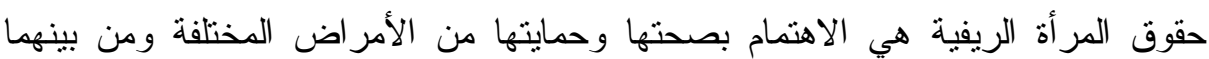

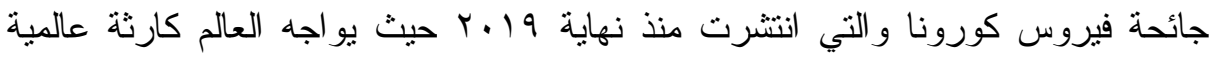

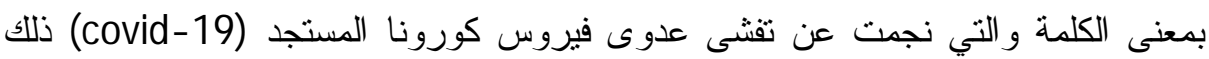

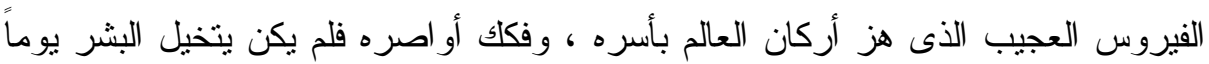

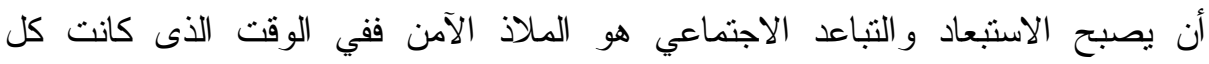
النظريات العلمية تدعو البشر للاندماج و التعايش الاجتماعي جاءت تلأك الجائحة لتهدم كل

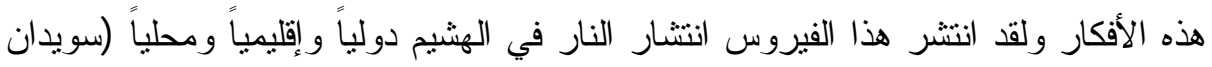

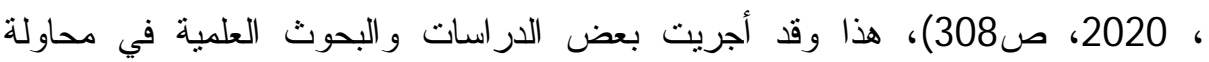

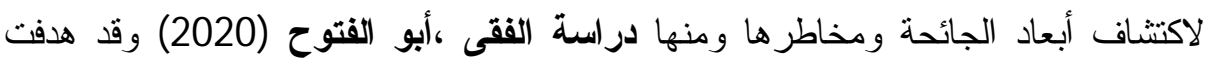

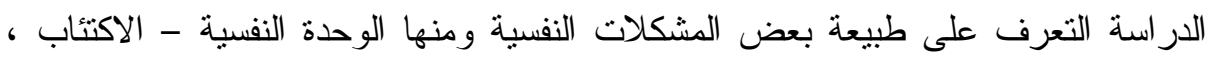

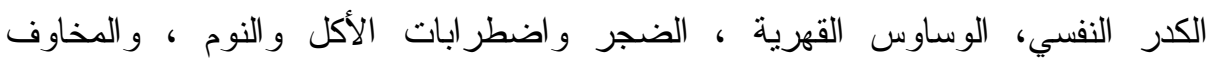

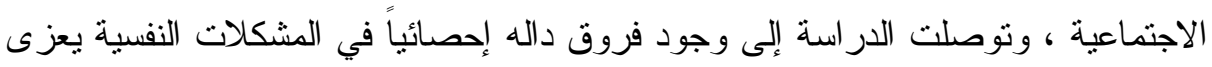

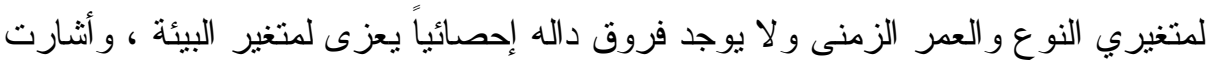

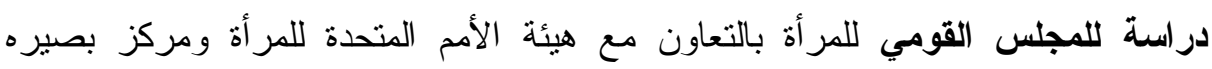

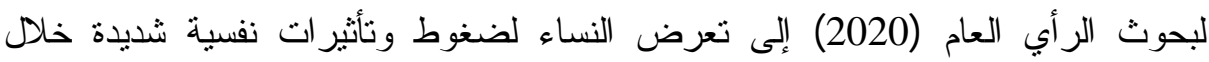

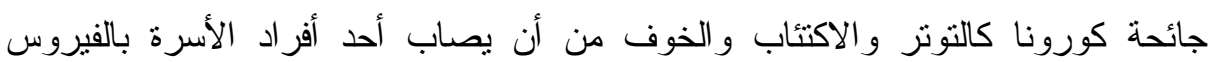

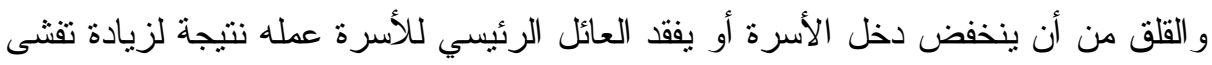

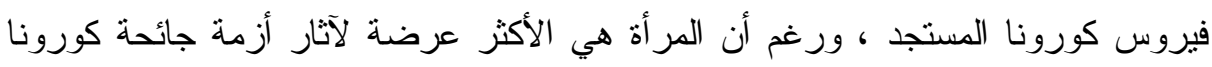

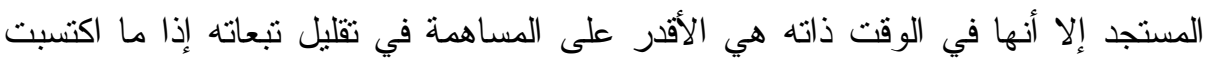

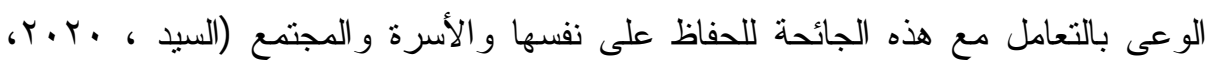

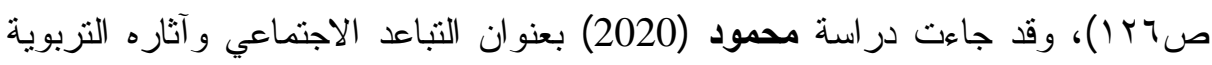

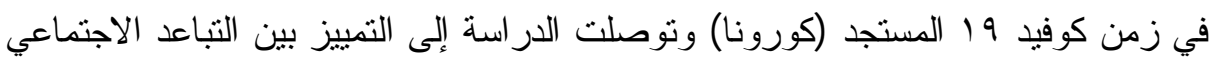

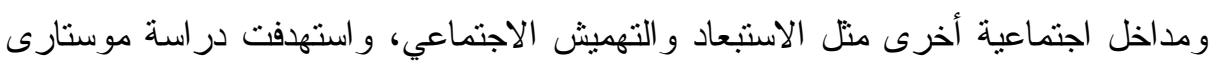

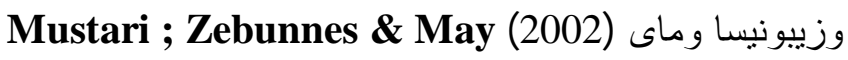

التعرف على تأثير كارثة كورونا على المرأة وأنه يجب على الجميع إنباع تعليمات الخبراء في الحفاظ على التباعد الاجتماعي لتجنب فيروس كورونا ، هذا وتعتبر الوحدات الصحية الريفية من أهم المنظمات الصحية بالمجتمع الريفي والملقى على عاتقهاعيات تقديم 
الرعاية الصحية المتكاملة لسكان الريف و التي تعتبر أحد ركائز التتمية المتواصلة ، وتقدم الوحدات الصحية الريفية خدمات الرعاية الصحية الأولية وتثمل التثقيف الصحي من قبل الربل الرائدات الريفيات - النطعيمات - الرعاية العلاجية لبعض الأمراض الثائعة (جمعية

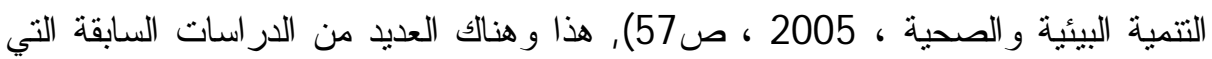

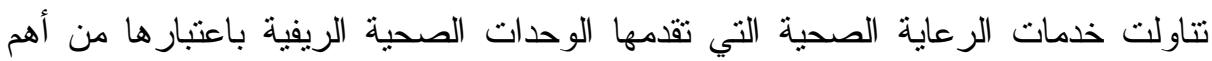

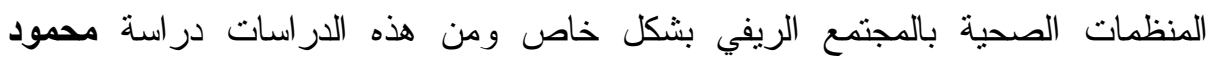

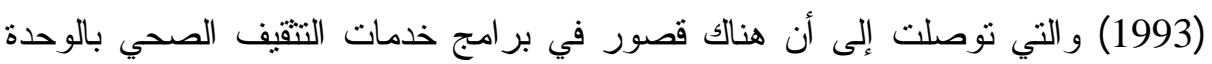

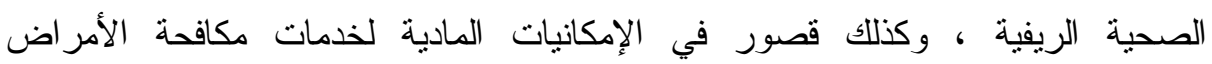

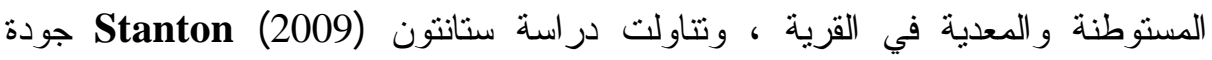

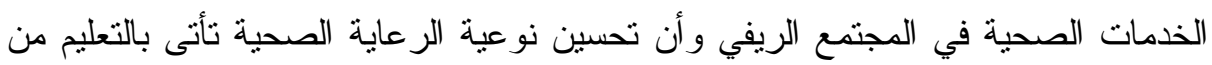

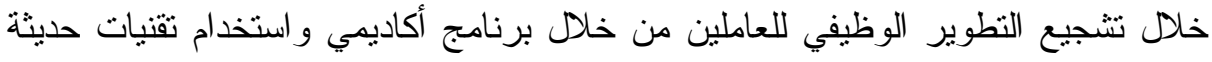

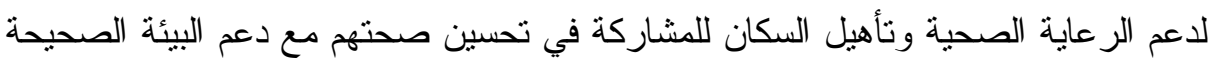

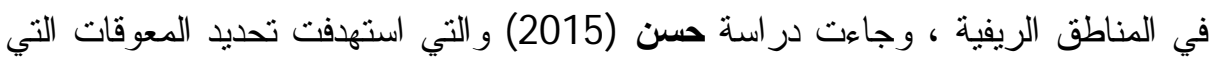

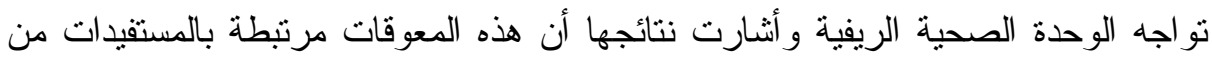

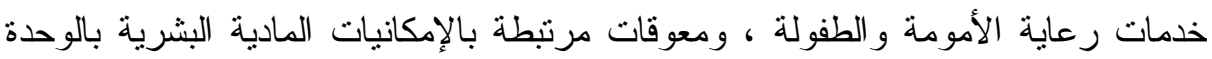

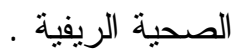

\section{وباستقر اء وتحليل الدراسات و الكتابات السابقة يتضح لنا ما يلى :}

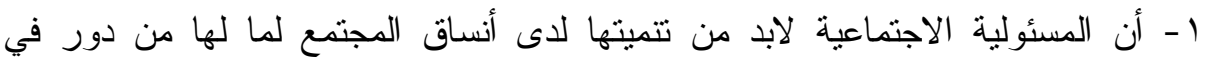

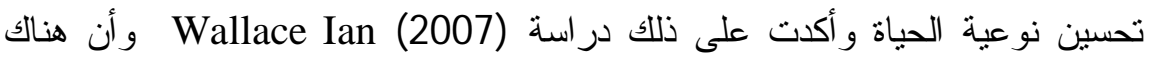
أبعاد لتحقيق المسئولية الاجتماعية وتتميتها و أكدت ذللك دراسة (2002)

$$
\text { Fukuda }
$$

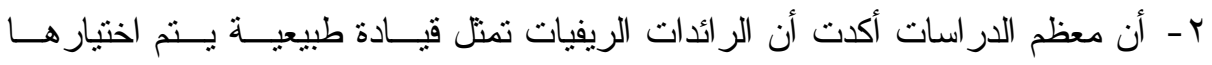

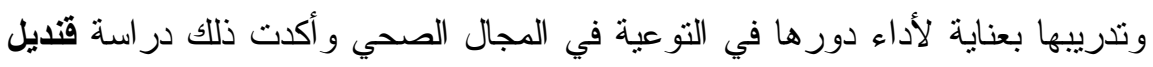

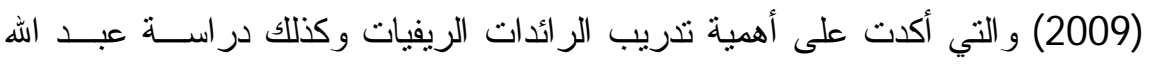

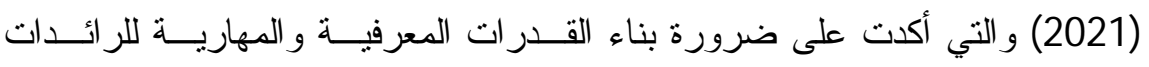
الريفيات

r - أن معظم الدراسات أكدت أن المرأة الريفية تمثل قطاع عريض في المجتمع و أنها

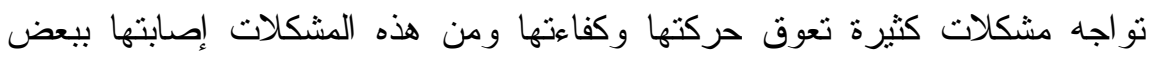




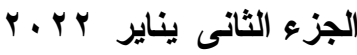

OV العدد

مجلة در استات في الخدمة الاجتماعية

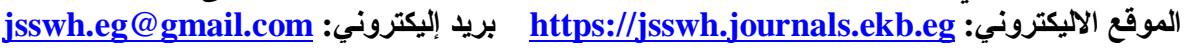

الأمر اض لذا لابد من توعيتها وحمايتها من هذه الأمر اض المختلفة و الاهتمام بصحتها

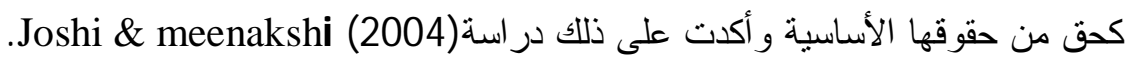
ع - أكدت الدراسات و البحوث العلمية أن العالم واجه في الفترة الأخيرة انتشار لفيروس كورونا ذللك الفيروس الذى هز أركان العالم وامتدت أثناره لتشمل كل فئات المجتمع و لابد من محاولة اكتشاف أبعاد تلك الجائحة ومخاطر ها منل دراسة الفقى وأبو الفتوح (2020) ، وأن المر أة قد تعرضت لتأثنير ات نفسية شديدة خلال جائحة كورونا مثل

$$
\text { در اسة المجلس القومي للمر أة (2020) }
$$

ه - أوجه الاتفاق بين الاراسة الحالية والدراسات السابقة تتمثل فى : 1 - أن هنالك العديد من الدراسات أكدت على أهمية تتمية الإحساس بالمسئولية الاجتماعية لاى مختلف أفر اد المجتمع . r - أن هناك العديد من الدراسات أكدت على أهمية دور الر ائدات الريفيات في التوعية الصحية والتي لابد من تدريبها وبناء قدر اتها المعرفية و المهارىه حيث يقع على عاثقه المسئولية الاجتماعية نحو توعية فئات المجتمع من الأمراض والأوبئة المختلفة .

7 - مدى استفادة الدراسة الحالية من الار اسات السابقة :

1 - ساعدت الباحثة في صياغة مشكلة الدراسة وتحديد أهميتها و أهدافها وفروضها .

r - ساعدت الباحثة في تحديد مفاهيم الدر اسة واختبار أداه جمع البيانات المناسبة . ب - أنه لا يوجد أي من الدراسات الوصفية لوصف وتحديد المسئولية الاجتماعية للر ائدات الريفيات بالوحدات الصحية الريفية في توعية المرأة الريفية بمخاطر جائحة كورونا لذلك وجدت الباحثة ضرورة التركيز على ذلك في هذه الدراسة. ثاتياً : الموجهات النظرية للار اسة :

في ضوء ما تقدم يمكن انتقاء أكثر النظريات فاعلية بما يتتاسب و هذه الدراسة وهى :

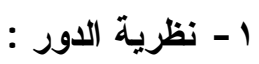

تعتمد الدر اسة الراهنة على نظرية الدور كموجه نظري لها ويشير مضمون نظرية الدور أن كل فرد يشغل مركزاً اجتماعيا في السلم الاجتماعي وهذا المركز يحتم على الذى لهى يشغله مجموعة من الحقوق والالتزامات التي تتظم تفاعله مع الآخرين الذين يشغلون مر اكز اجتماعية أخرى ، وعندما يضع الفرد الثاغل لمركز معين عناصر المر اكز من الحقوق و الو اجبات موضع التنفيذ حينئذ يمارس دوراً (قاسم ، 1990،صنما 34) . 


\section{ويعرف الاور في قاموس العلوم الاجتماعية بأنه :}

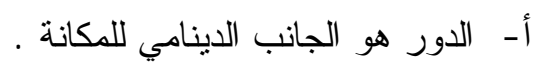

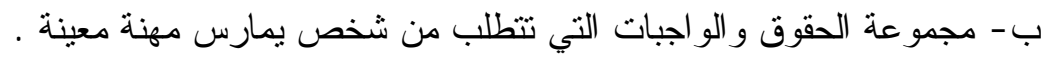
ج - مجموعة القيم و السلوكيات التي تصف مكان معينه .(,p.18

\section{ويرتبط مفهوم الدور بعدة مفاهيم وهى :}

1 - نوقعات الدور : وهى مجموعة التوقعات لسلوك شخص ولثو أو مركز يتو لاه شخص معين

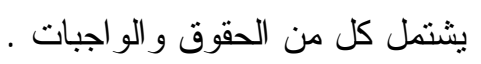

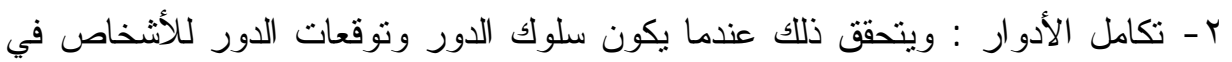

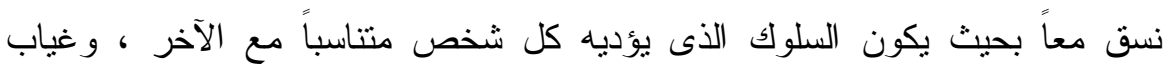

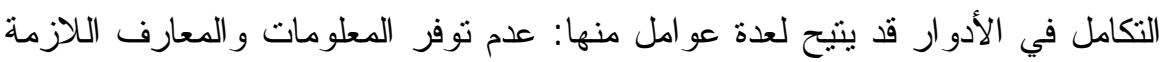

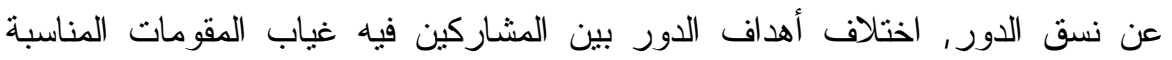
لتسهيل مهام الدور (Francis.J.turner,1986,p.542). r - أداء الدور : وهو السلوك الذى يؤديه شاغل المكانة المعينة ، وبناءا على ما تعلمه في الكي وقت سابق ويهدف إلى تحقيق غاية معينة .

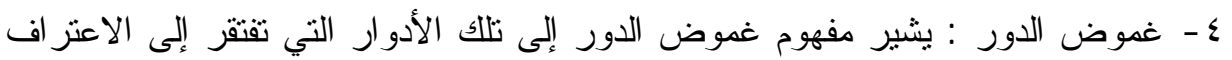

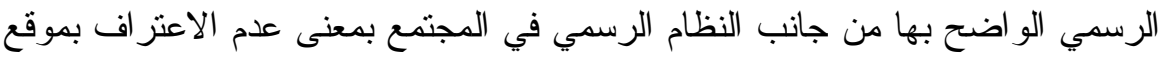

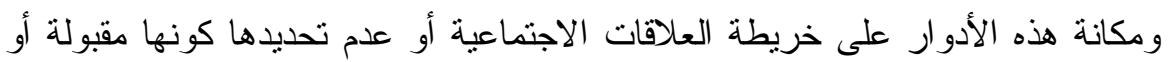

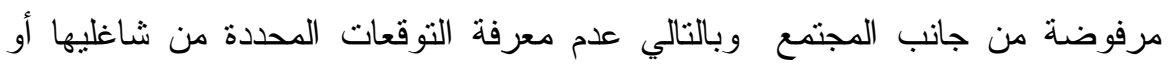

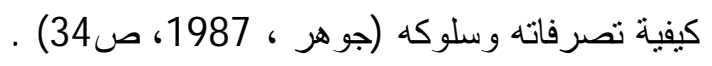

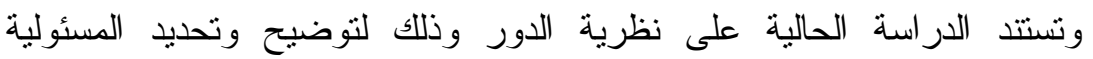
الاجتماعية للر ائدات الريفيات بالوحدات الصحية الريفية في تتمية الوعى لدى المر أة الريفية

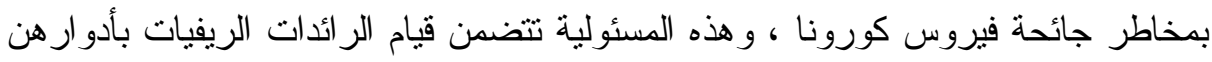

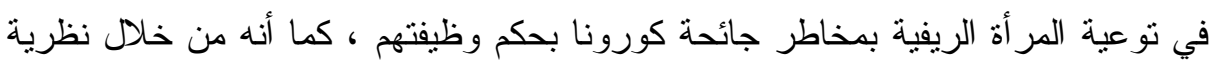

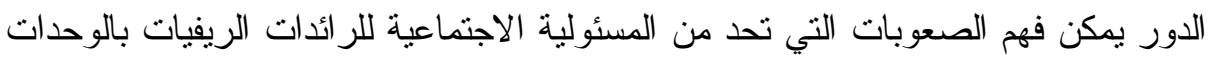

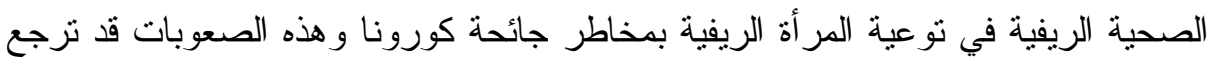

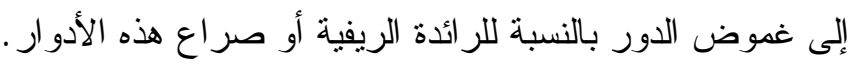


ثالثا : تحديد مشكلة الدر اسة وصياغتها :

انطلاقا من العرض السابق وفى ضوء أدبيات موضوع الدر اسة المتصلة بكتابات مشكلة الدراسة والدر اسات السابقة فقد تبلورت مشكلة الدراسة وتم صياغتها في التساؤل التالي : ما مستوى المسئولية الاجتماعية للرائدات الريفيات بالوحدات الصحية وتتمية الوعى لاى المر أة الريفية بمخاطر جائحة فيروس كورونا؟

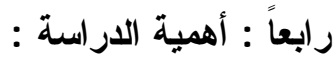

1 - خطورة جائحة فيروس كورونا على مختلف فئات المجتمع وكافة نو احي الحياه . r - تتمية الإحساس بالمسئولية الاجتماعية للرائدات الريفيات بالوحدات الصحية

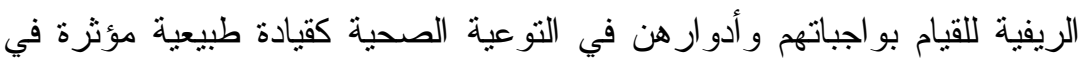

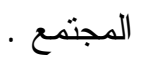
r - تعد المرأة الريفية من الموارد البشرية الهامة في المجتمع لذا ينبغي رعايتها

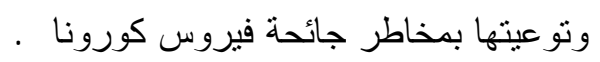
ـ - أن طريقة تتظيم المجتمع كإحدى طرق الخدمة الاجتماعية تقوم على التخطيط العلمي لمعاونة المجتمعات المحلية على مواجهة مشاكلها وإثباع احتياجاتها الأساسية بأسلوب فعال بدعم التر ابط الاجتماعي في المجتمع ويحقق زيادة قدراته في مو اجهة مشكلاته المستقبلية (بدران ، 1969، ص ص بس بل 79 -80) . 0 - لا توجد أي من الدراسات العلمية "على حد علم الباحثة" نتاولت المسئولية الاجتماعية للر ائدات الريفيات بالوحدات الصحية في توعية المر أة الريفية بمخاطر لور جائحة فيروس كورونا لذا وجدت الباحثة ضرورة التركيز على توضيح ذلك

\section{خامسا: أهداف الدر اسة:}

1. . تحديد مستوى المسئولية الاجتماعية للر ائدات الريفيات بالوحدات الصحية الريفية. r . تحديد مستوى أبعاد تتمية الوعي لدى المر أة الريفية بمخاطر جائحة فيروس كورونا. r. تحديد الصعوبات التي تواجه تحمل الرائدات الريفيات بالوحدات الصحية للمـسئولية

الاجتماعية في تتمية الوعي لدى المر أة الريفية بمخاطر جائحة فيروس كورونا. ع. . تحديد مقترحات تفعيل المسئولية الاجتماعية للر ائدات الريفيات بالوحدات الــصحية في تتمية الوعي لدى المر أة الريفية بمخاطر جائحة فيروس كورونا. 


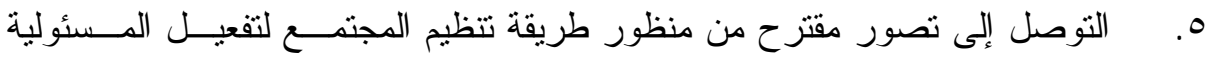

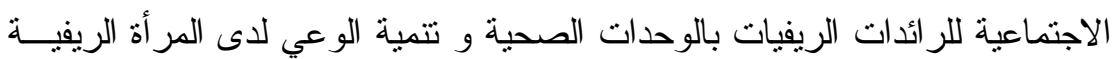

$$
\begin{aligned}
& \text { بمخاطر جائحة فيروس كورونا. } \\
& \text { سادسا: فروض الارسة: }
\end{aligned}
$$

الفرض الأول للاراسة: " من المتوقع أن يكون مـستوى المـسئولية الاجتماعيــة

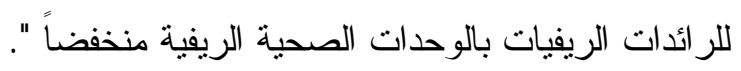

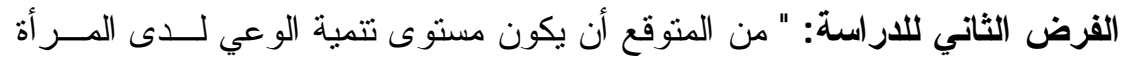

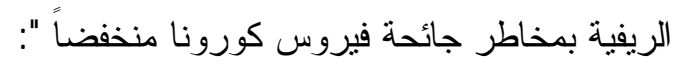

\section{ويمكن اختبار هذا الفرض من خلا الأبعاد التالية}

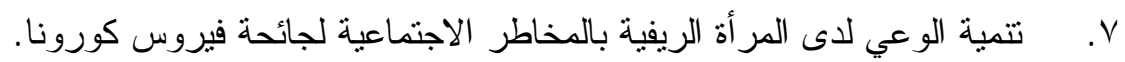

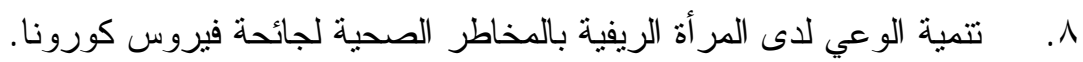

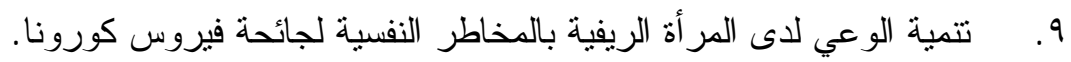

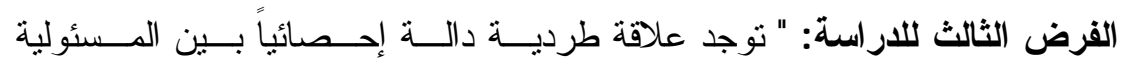

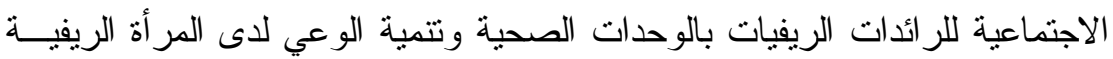

$$
\text { بمخاطر جائحة فيروس كورونا ". }
$$

(V)

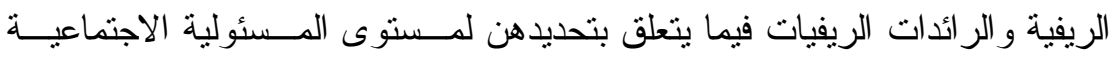

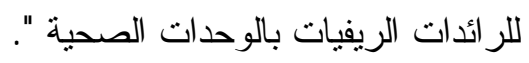

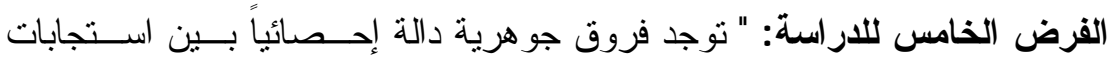

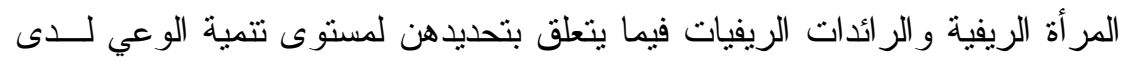
المرأة الريفية بمخاطر جائحة فيروس كورونا ".

$$
\text { سابعاً : مفاهيم الاراسة : الرانة }
$$

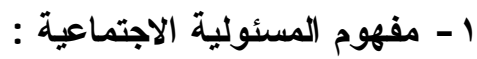

تحدد دائرة معارف الرعاية الاجتماعية N.Y.S.W مفهوم المسئولية الاجتماعية

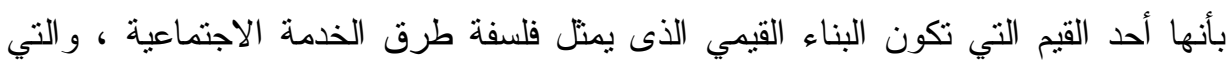

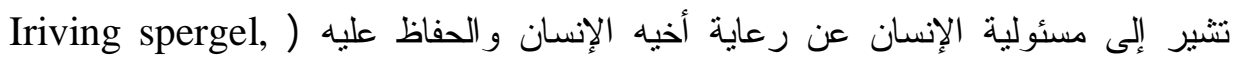


ويعرف قاموس مصطلحات الخذمة الاجتماعية المسئولية الاجتماعية على أنها

إدراك ويقظة الفرد و وعى ضميره وسلوكه للواجب الثخصي و الاجتماعي (الدخيل ، . (550)2006

ويعرف جرو سنكل Grossniekle المسئولية الاجتماعية بأنها عملية تقدير الفرد

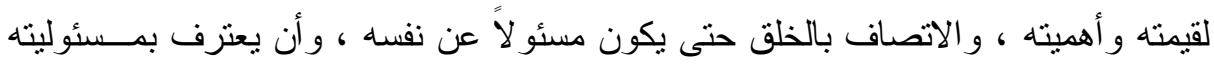
نحو الآخرين (Grossnikleo,1992,P.25) .

وقد حدد سيد أحمد عثمان عناصر المسئولية الاجتماعية في ( الاهتمام ، الفهم

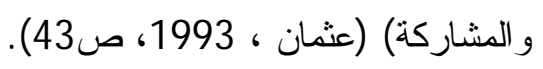

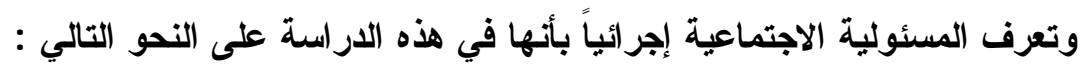

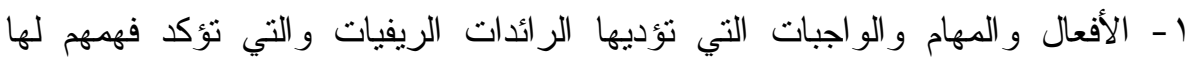

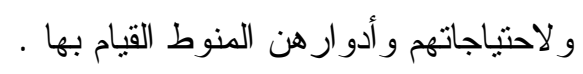

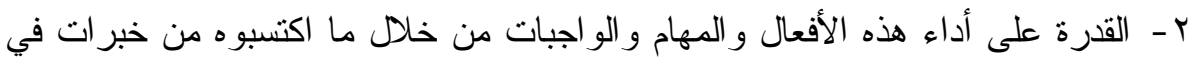

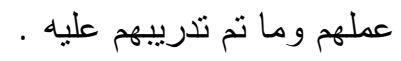

r - هذه المسئولية قد تكون مسئولية ذاتية تجاه الفرد ونفسه أو مسئولية تجاه الآخرين ، أو

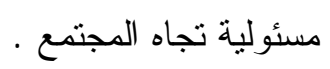

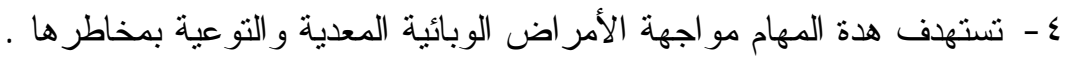

$$
\text { r }
$$

تعرف الر ائدة الريفية بأنها : قيادة طبيعية ينم اختيار ها من القرية التي تعيش فيها ويتم

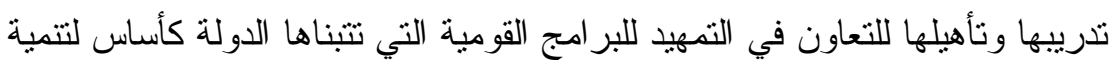

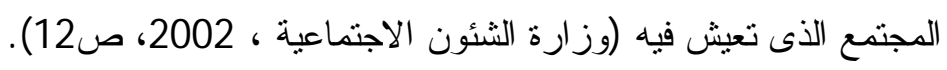

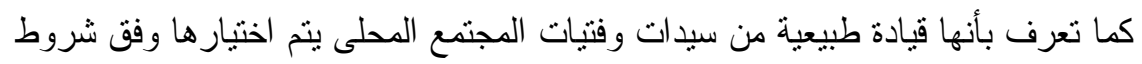

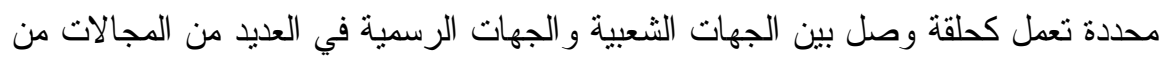

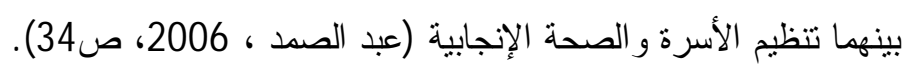

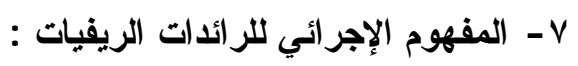
1 - قيادة طبيعية نسائية .

r - يتم إعدادهن إعداداً مهنياً وتدريبهن للتعامل مع المر أة الريفية وتو عيتها 
r - من أهم القيادات المؤثرة وتسعى إلى تمكين وعى المر أة الريفية بالمشكلات

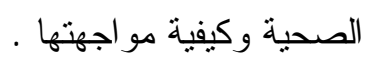

\section{r - مفهوم الوحدات الصحية الريفية :}

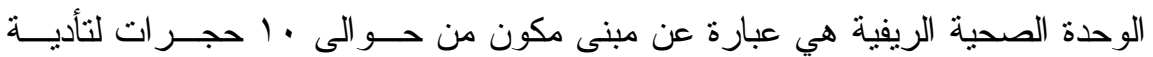

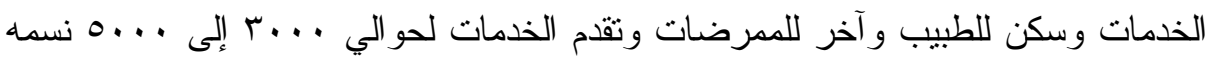
من السكان ويتكون الفريق الصحي بالوحدة الصحية الريفية من طبيب أو أكثر - ممرضنين

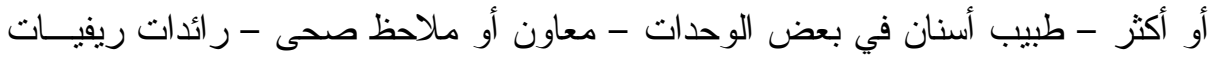

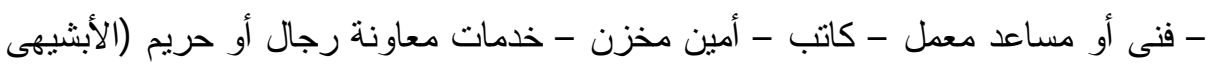

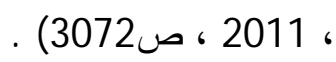

$$
\text { ؛ - مفهوم الوعى : }
$$

يشير مفهوم الوعى في اللغة بأنه الإدرالك والإحاطة (مجمع اللغة العربية ،

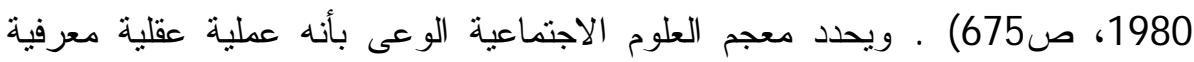

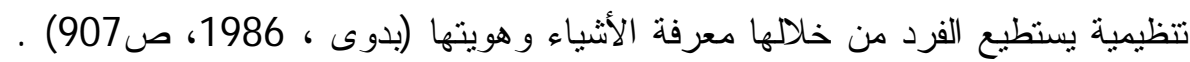
ويعرف الوعى بأنه اكتساب الفرد لخبرات ومعلومات وعادات (راجح ، 1985 ،

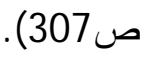

\section{وتقصد الباحثة في هذه الار اسة مفهوم الوعى ما يلي :}

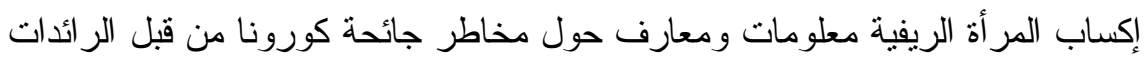

الريفيات بالوحدات الصحية الريفية.

\section{ه - مفهوم جائحة فيروس كورونا :}

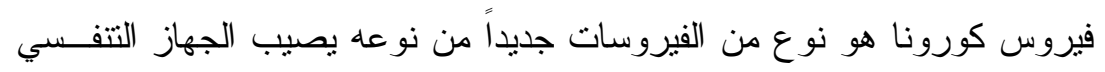

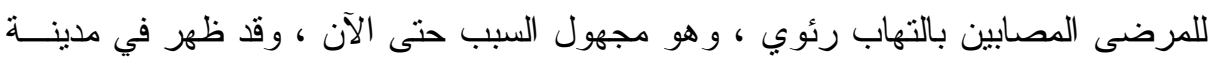

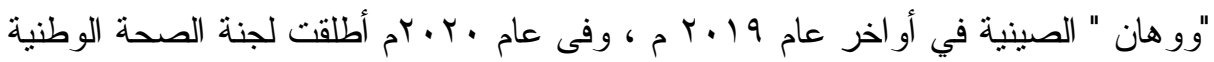

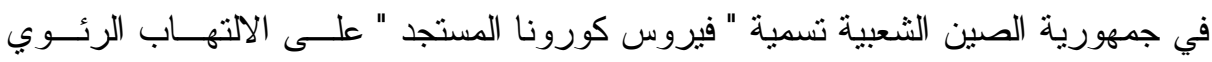

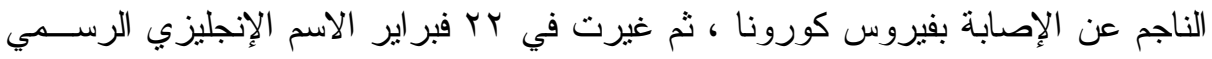

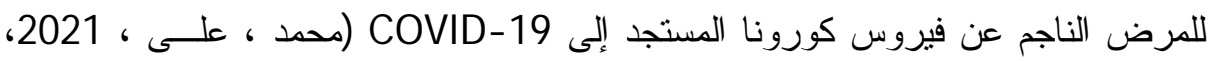

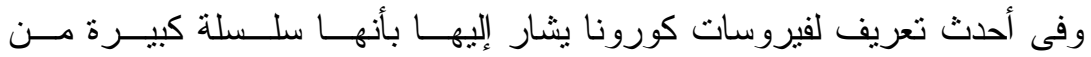

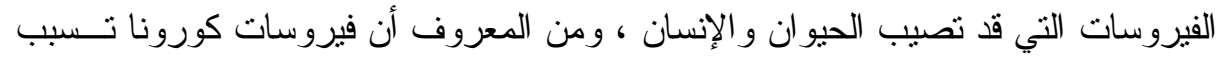

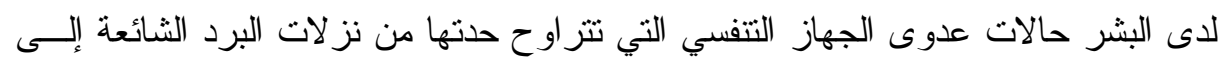

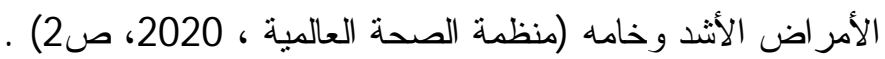




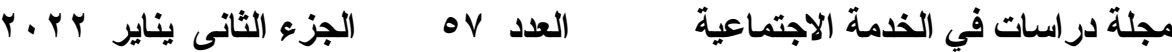

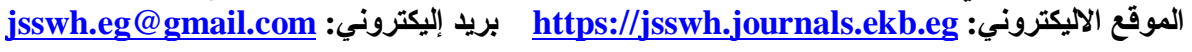

ويثير مفهوم جائحة فيروس كورونا كما يلى : 1 - فيروس جديداً من نوعه ظهر في مدينة "وو هان" الصينية .

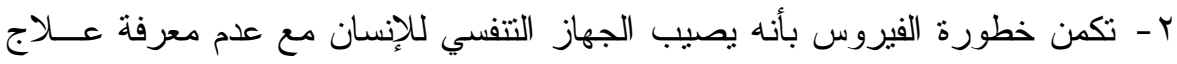

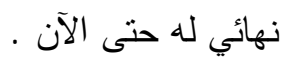

r - هذا الفيروس نتج عنه مجموعة من المخاطر الاجتماعية و النفسية والصحية.

ثامنا: الإجر اعات المنهجية للار اسة:

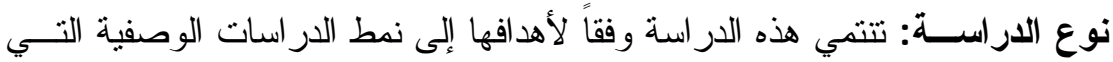

تصور الواقع وتشخصه وتسهم في تحليل ظو اهره، وكذلك فالدر اسات الوصفية لايها

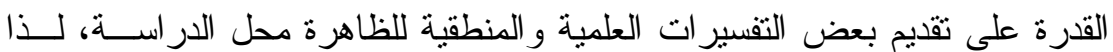
فالدر اسة الحالية تستهدف وصف وتحديد المسئولية الاجتماعية للر ائـدات الريفيـات

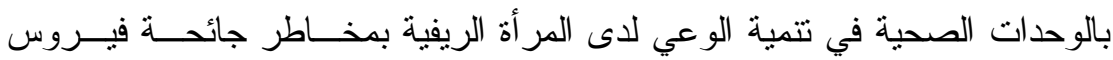

كورونا

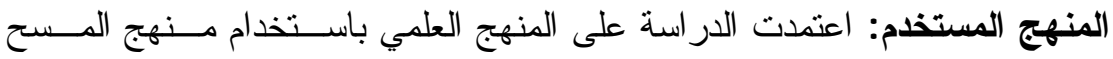

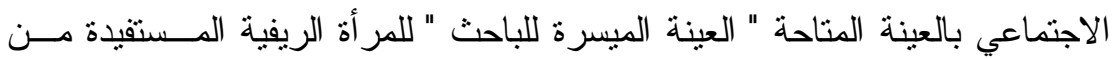

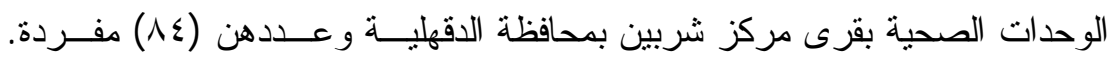

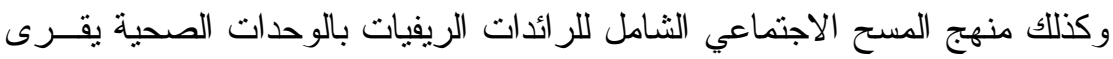
مركز شربين بمحافظة الدقهلية و عددهن (هو (الماعي مفردة.

$$
\text { وتوزيعهن كالتالي: }
$$

\begin{tabular}{|c|c|c|c|}
\hline عداد الرائدات الريفيات & عدلد المر أة الريفية & اسم الوحدة الصحية & s \\
\hline $\bar{T}$ & $\bar{\Gamma}$ & الوحدة الصحية بقرية منشأة عزت & 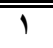 \\
\hline $\bar{T}$ & $\bar{\Gamma}$ & الوحدة الصحيةّ بقرية العوضية & $\overline{c r}$ \\
\hline $\bar{T}$ & $\bar{T}$ & الوحدة الصحية بقرية البرامنة & $\bar{\Gamma}$ \\
\hline 1 & $\bar{Y}$ & الوحلة الصحية بقرية موسى شكري & $\varepsilon$ \\
\hline 1 & r & الوحدة الصحية بقرية ترعة غتيم & 0 \\
\hline 1 & $r$ & الوحدة الصحية بقرية الجلاوينة & 7 \\
\hline$T$ & $r$ & الوحدة الصحية بقريةٌ منشاة مبارك & $\mathrm{v}$ \\
\hline$r$ & $r$ & الوحدة الصحيةً بقرية الثناوي & $\Lambda$ \\
\hline 1 & $\bar{r}$ & الوحدة الصحية بقرية أبو سيد احمد & 9 \\
\hline $\bar{r}$ & $\bar{r}$ & اللوحدة الصحية بقرية كفر الحاج شربيني & 1. \\
\hline $\bar{r}$ & $\bar{r}$ & الوحدة الصحية بقرية محلة إنجاق & 11 \\
\hline $\bar{r}$ & $\bar{r}$ & اللوحدة الصحيةٌ بقرية كفر أبو زاهر & IT \\
\hline $\bar{r}$ & $\bar{r}$ & الوحدة الصحية بقرية كفر الوكالةً & 14 \\
\hline
\end{tabular}

جدول رقم (1) يوضح توزيع المر أة الريفية والرائدات الريفيات مجتمع الدراسة : 


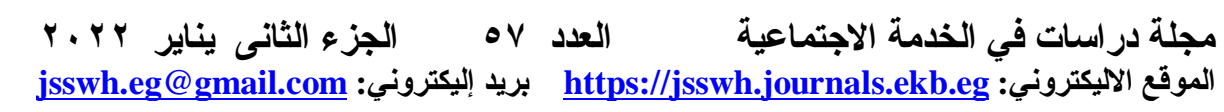

\begin{tabular}{|c|c|c|c|}
\hline عدد الر ائدات الريفيات & عدد المر أة الريفية & اسم الوحدة الصحية & ק \\
\hline$\overline{\bar{r}}$ & $\overline{\bar{Y}}$ & الوحدة الصحية بقريةة الصعديةً & 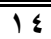 \\
\hline 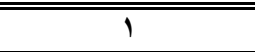 & $\bar{r}$ & الوحدة الصحية بقرية كفر الحطبة & 10 \\
\hline 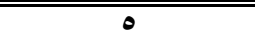 & 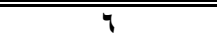 & الوحدة الصحية بقرية بساط كريم الدين & 17 \\
\hline$r$ & $\bar{\mu}$ & الوحدة الصحية بقرية منشاة النصر & IV \\
\hline 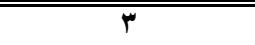 & 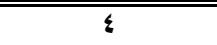 & الوحدة الصحية بقرية دنجواي & 11 \\
\hline 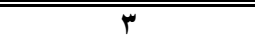 & $\overline{\varepsilon \varepsilon}$ & الوحدة الصحية بقرية الضهرية & 19 \\
\hline $\bar{r}$ & $\bar{r}$ & الوحدة الصحية بقرية أبو جلال & r. \\
\hline 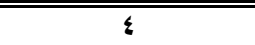 & $\overline{0}$ & الوحدة الصحية بقريةٌ التزعة الجديا & 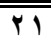 \\
\hline 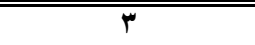 & $\bar{\mu}$ & الوحدة الصحية بقرية الأحمدية & 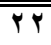 \\
\hline $\bar{r}$ & $\bar{\mu}$ & الوحدة الصحية بقرية رأس الخليج & $\overline{r r}$ \\
\hline $\bar{r}$ & $\overline{T r}$ & الوحدة الصحية بقرية كفر يوسف & 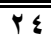 \\
\hline $\bar{\mu}$ & $\bar{\varepsilon}$ & الوحدة الصحية بقرية كفر الأطرش & Yo \\
\hline$\overline{11}$ & 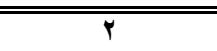 & الوحدة الصحيةٌ بقريةٌ مقري الحصص & YY \\
\hline $\bar{r}$ & 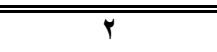 & الوحدة الصحية بقرية العيادية & TrV \\
\hline$\overline{1}$ & $\bar{Y}$ & الوحدة الصحية بقرية الحصص & $\overline{r \Lambda}$ \\
\hline $\bar{r}$ & $\bar{\mu}$ & الوحدة الصحية بقرية أبو شعير & rq \\
\hline$\overline{1}$ & $\bar{r}$ & الوحدة الصحية بقرية بوشنه & 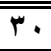 \\
\hline 09 & 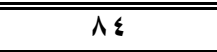 & الإجمالي & \\
\hline
\end{tabular}

المجال المكاني: تمثل المجال المكاني للدر ساسة في الوحدات الصحية الريفية بقــى

بمركز شربين بمحافظة الدقهلية.

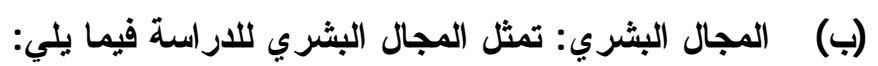

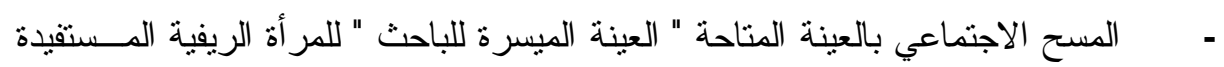

من الوحدات الصحية بمركز شربين بمحافظة الدقهلية و عددهن (عـ) مفردة.

المسح الاجتماعي الثامل للر ائدات الريفيات بالوحدات الصحية الريفية بقرى بمركز

شربين بمحافظة الدقهلية و عددهن (1اعي الوه ) مفردة.

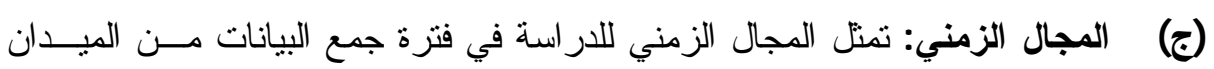

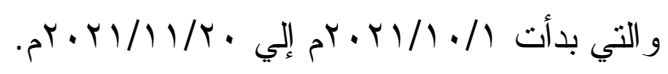




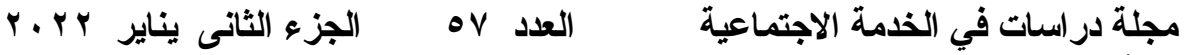
الموقع الاليكتروني:

(ع - 1) (ستمارة استبيان للمر أة الريفية حول المسئولية الاجتماعية للرائدات الريفيـات

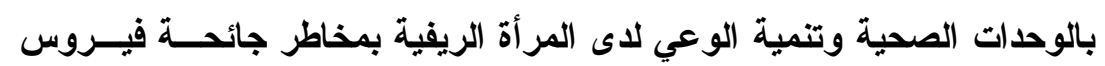

كورونا:

قامت الباحثة بتصميم استمارة استبيان للمر أة الريفية وذلك بالرجوع عإلــى الأدبيــات

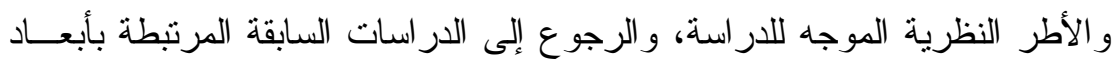
الدر اسة. اثتثملت استمارة استبيان المر أة الريفية على المحـــاور التاليـــة: البيانــات الأوليــة،

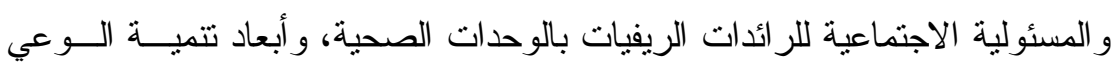

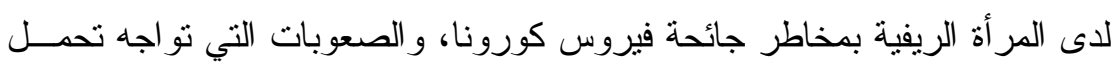

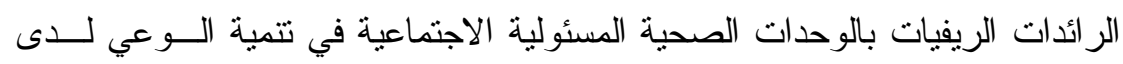
المر أة الريفية بمخاطر فيروس كورونا، ومقترحات تفعيل المـسئولية الاجتماعيــة

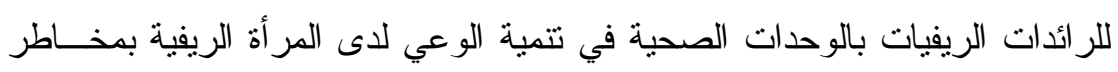
فيروس كورونا. وقد أجرت الباحثة الصدق الظاهري لاستمارة استبيان المرأة الريفية بعد عرضـــها عدد (0) محكمين من أعضاء هيئة التدريس بكلية الخدمة الاجتماعية جامعة حلوان و المعهد العالي للخدمة الاجتماعية بالمنصورة لإبداء الر أي في صلاحية الأداة مسنـ

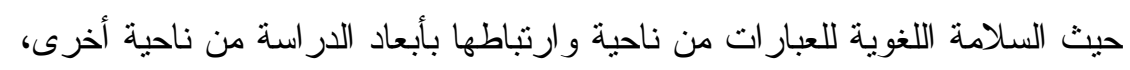

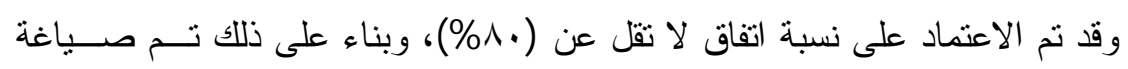
الاستمارة في صورتها النهائية.

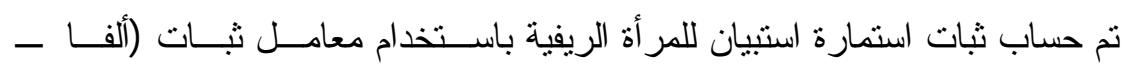

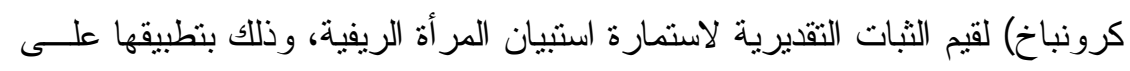

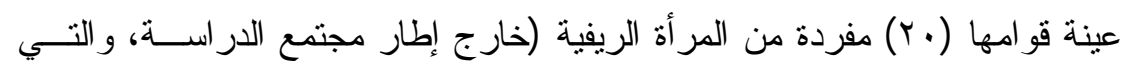

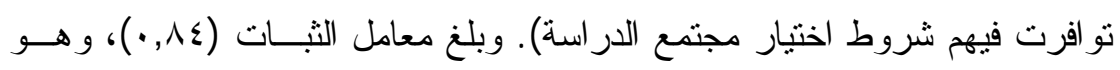
مستوى مناسب للثبات الإحصائي. 


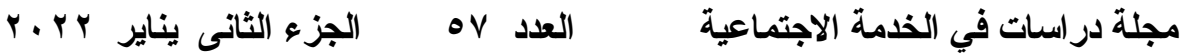

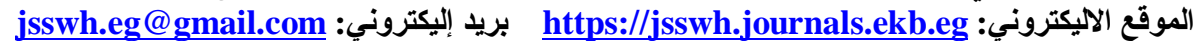

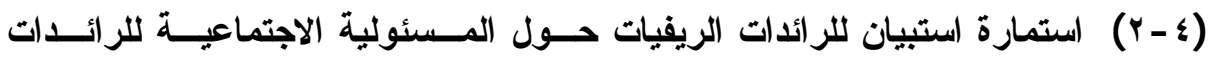

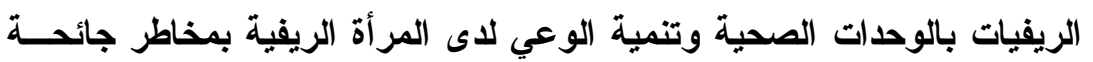

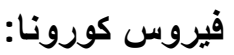

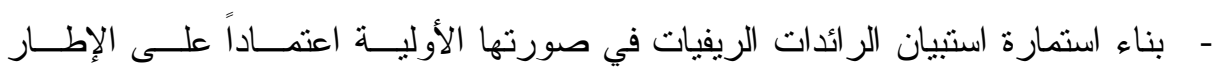

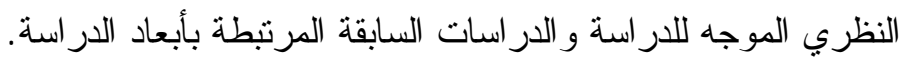

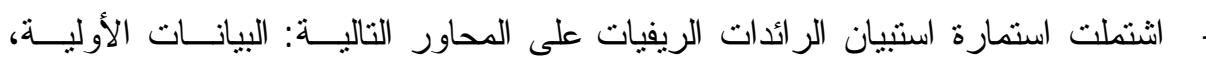

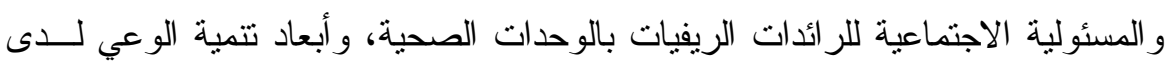

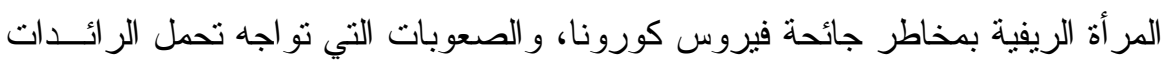

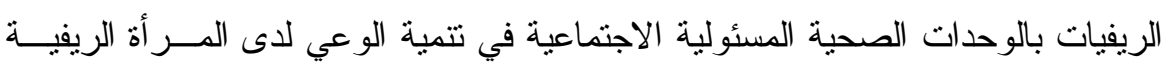

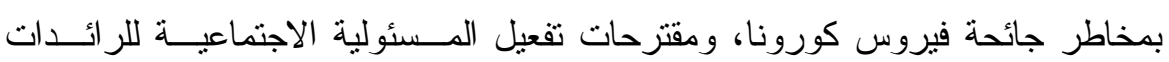

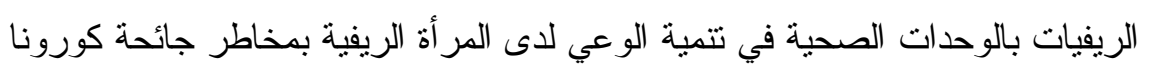

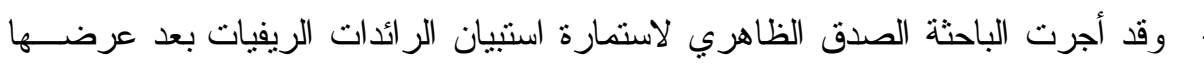

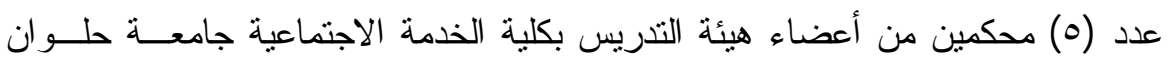

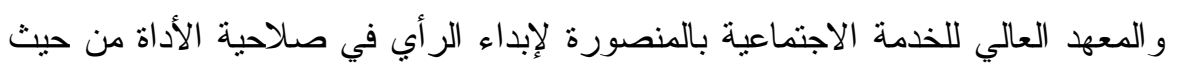

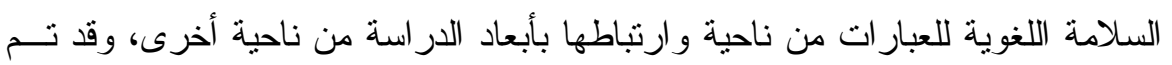

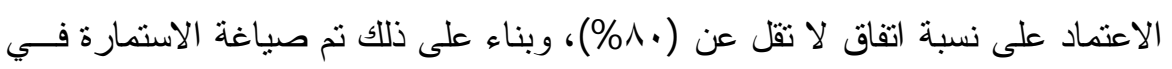
صورتها النهائية.

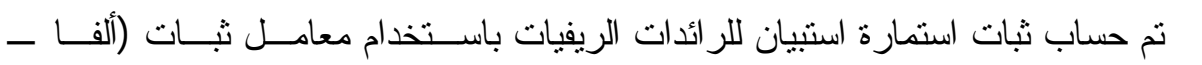

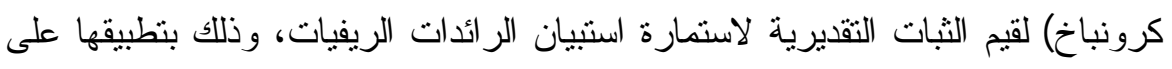

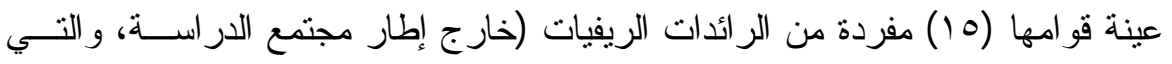

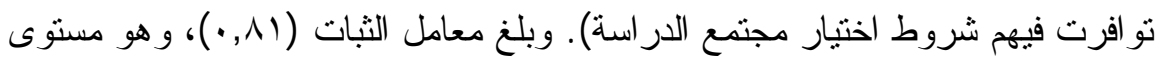

$$
\text { مناسب للثبات الإحصائي. }
$$

تحديد مستوى المسئولية الاجتماعية للرائدات الريفيات بالوحدات الصحية الريفية:

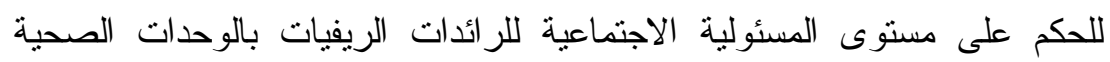

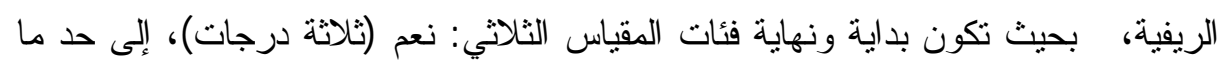

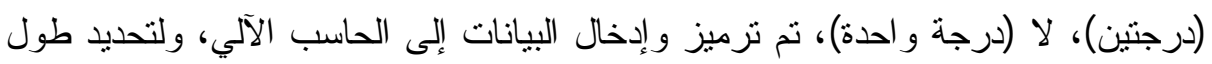

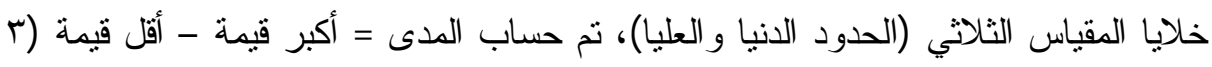

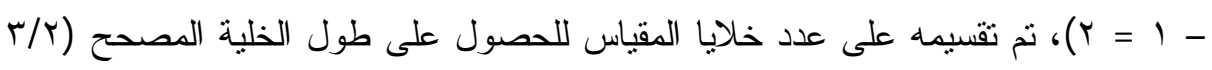
ال TV =

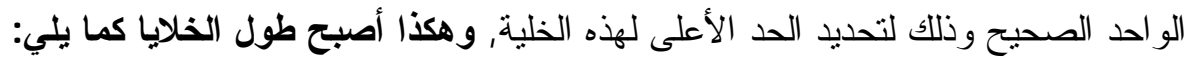




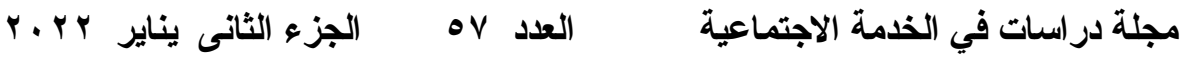
الموقع الايكتروني:

جدول رقم (r) يوضح مستويات المتوسطات الحسابية لأبعاد الدراسة:

\begin{tabular}{|c|c|}
\hline 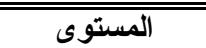 & القير \\
\hline مستوى منخفض & إذذا تراوحت قيمة المتوسط للعبارة أو البعد من 1 إلى VI, I T \\
\hline مستوى متوسط & 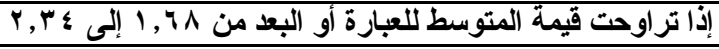 \\
\hline مستوى مرتفع & 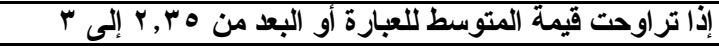 \\
\hline
\end{tabular}

(7) أساليب التحليل الإحصائي:

تم معالجة البيانات من خلال الإسائ الآل الآلي باستخدام برنامج الحزم الإحصائية

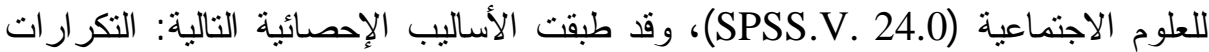

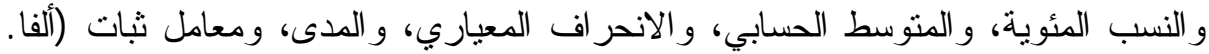

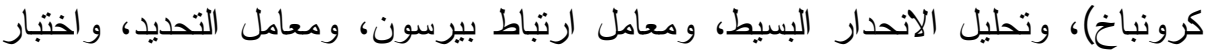
(ت) لعينتين مستقلنين، وتحليل التباين أحادي الاتجاه. نتائج الارساسة الميدانية:

المحور الأول: وصف مجتمع الاراسة:

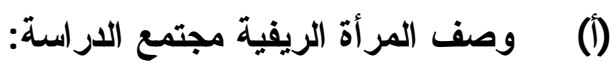

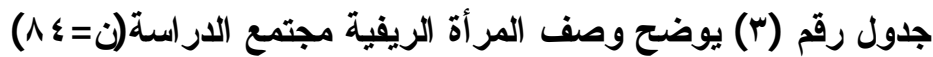

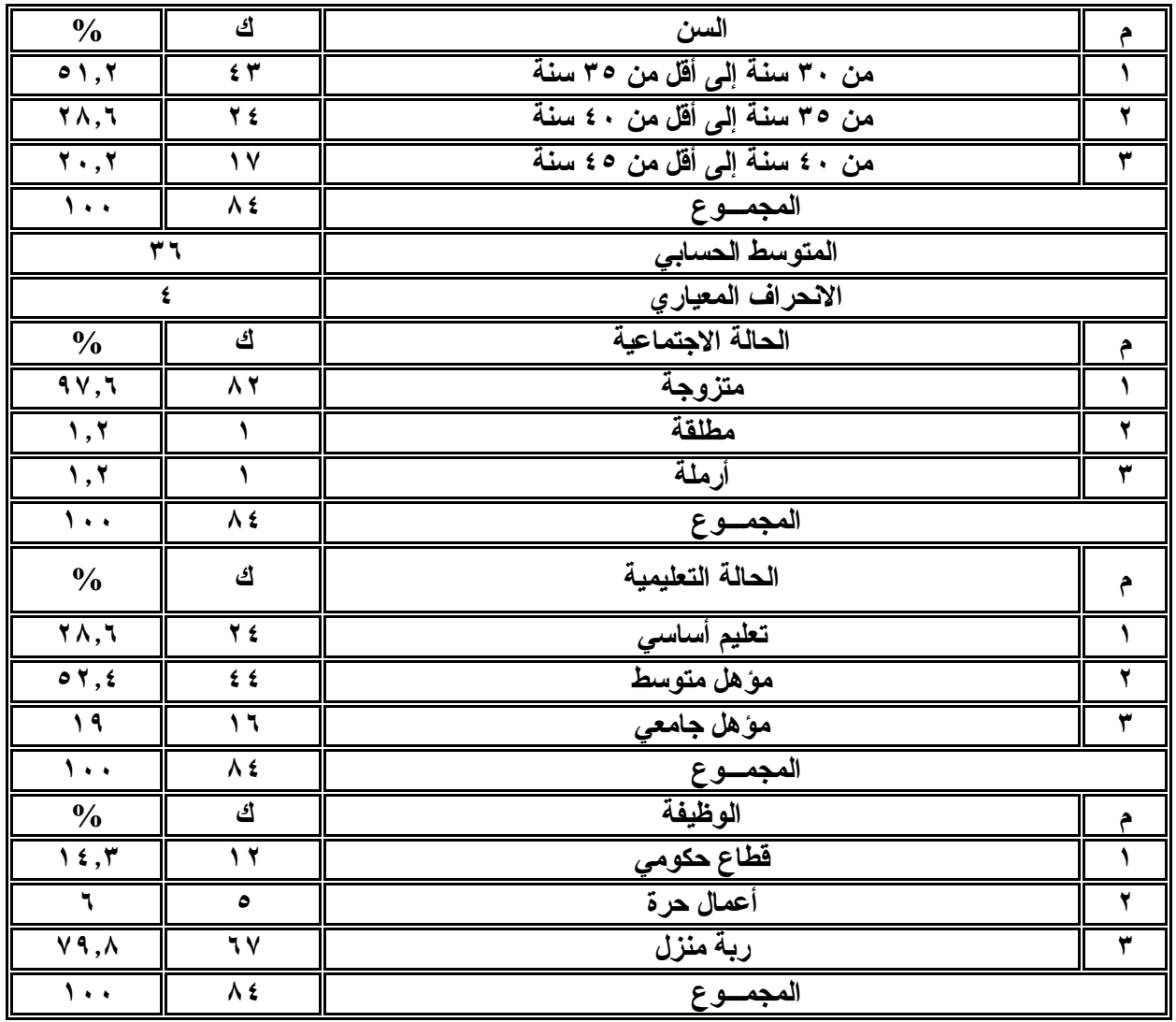




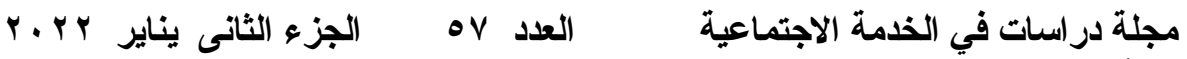
الموقع الايكتروني:

\section{يوضح الجدول السابق أن:}

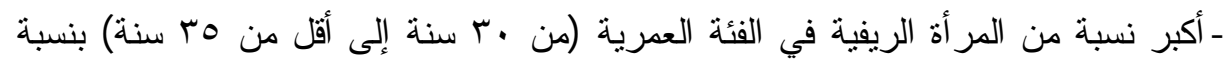

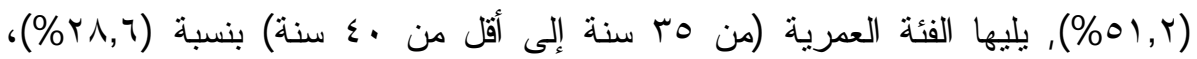

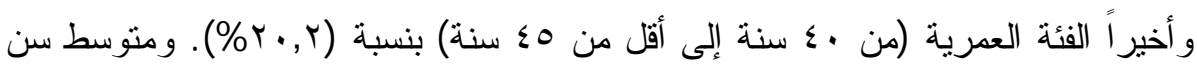

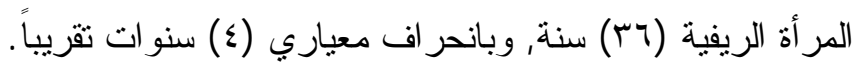

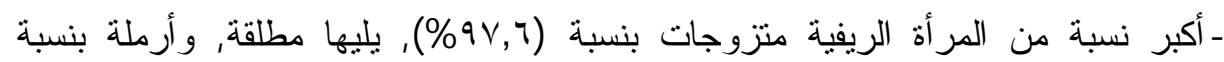

$$
.(\%), r)
$$

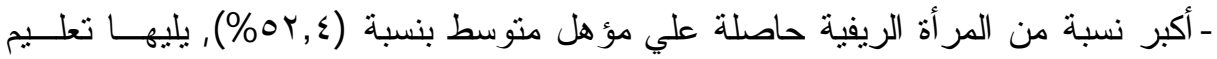

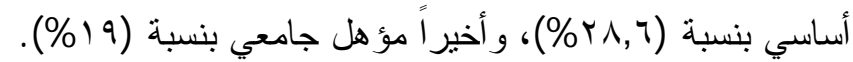

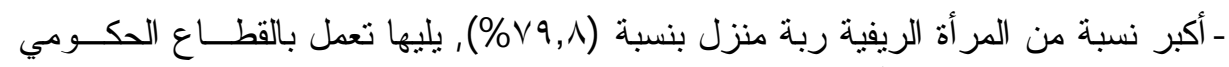

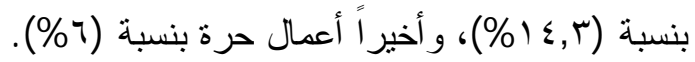

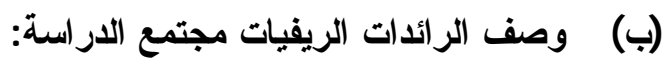

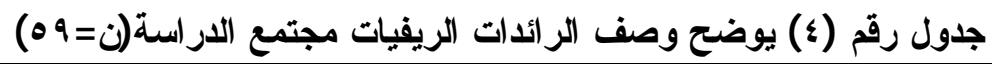

\begin{tabular}{|c|c|c|c|}
\hline$\%$ & ك5 & السن & م \\
\hline 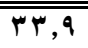 & 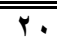 & 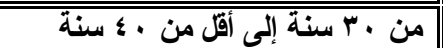 & 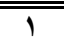 \\
\hline$\overline{c o v, 4}$ & 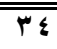 & من · ؛ سنة إلى أقل من ·• سنةّ & 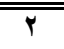 \\
\hline$\overline{1 \Lambda, 0}$ & 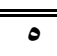 & 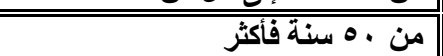 & $\overline{\nu r}$ \\
\hline $1 \ldots$ & 099 & \multicolumn{2}{|c|}{ المجمــوع } \\
\hline \multicolumn{2}{|c|}{$\varepsilon r$} & \multicolumn{2}{|c|}{ المتوسط الحسابي } \\
\hline \multicolumn{2}{|c|}{$\overline{71}$} & \multicolumn{2}{|c|}{ الاحمراف المعياري } \\
\hline$\%$ & s & | الحالة الاجتماعية | ل الحاعية | & " \\
\hline$\overline{\Lambda \uparrow \uparrow, \xi}$ & 01 & | متززوجة & 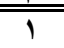 \\
\hline$\overline{l 1, \mathrm{~V}}$ & 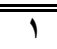 & 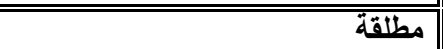 & 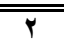 \\
\hline 11,9 & $\bar{v}$ & |أرملة & $\bar{\nu}$ \\
\hline$\overline{l 1}$ & 099 & \multicolumn{2}{|c|}{ المجمــوع } \\
\hline$\overline{\%}$ & (5) & | المؤهل الدر اسىى & 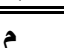 \\
\hline 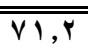 & ¿Y & |مؤهل متوسط & 1 \\
\hline$\overline{1 \lambda, 0}$ & 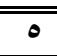 & |مؤهل فوق المتوسط & $\bar{Y}$ \\
\hline$\overline{r \cdot, r}$ & $1 \%$ & | مؤهل جامعي & $\bar{r}$ \\
\hline$\overline{c 1 . .}$ & 09 & \multicolumn{2}{|c|}{ المجمــوع المجـو } \\
\hline$\%$ & s & عدد سنوات الخبرة في مجال العمل & $\bar{~}$ \\
\hline 8,1 & 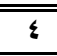 & من با سنوات إلى أقل من ح سنوات & 1 \\
\hline$\overline{\lambda 1,0}$ & 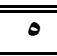 & من 7 سنوات إلى أقل من 9 سنوات & $\bar{r}$ \\
\hline$\overline{A \varepsilon, V}$ & 0. & |من 9 سنوات فأكثر & 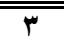 \\
\hline $1 \ldots$ & 09 & \multicolumn{2}{|c|}{ 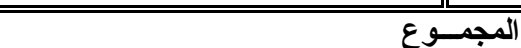 } \\
\hline \multicolumn{2}{|c|}{1.} & \\
\hline & & \multicolumn{2}{|c|}{ الالميد إفط المعابي ع } \\
\hline
\end{tabular}




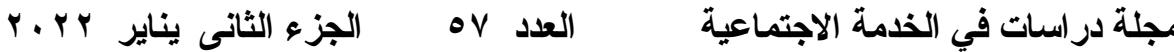

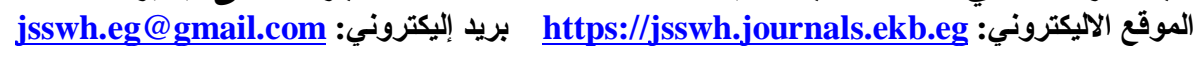

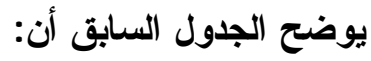

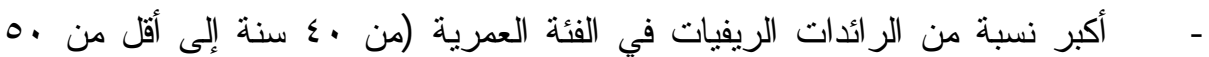

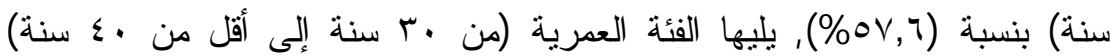

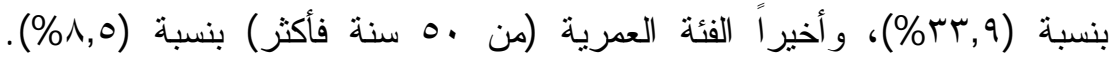

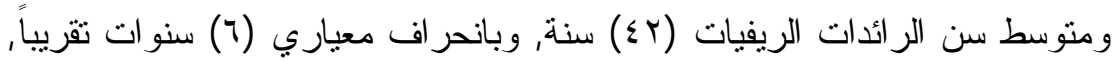

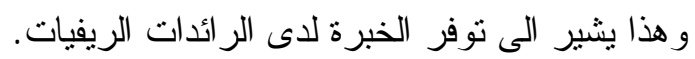

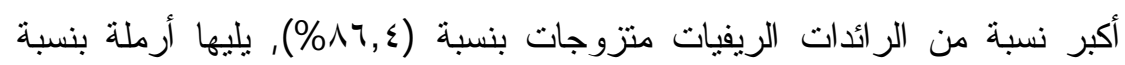

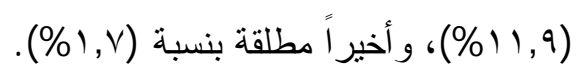

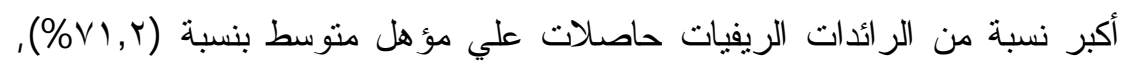

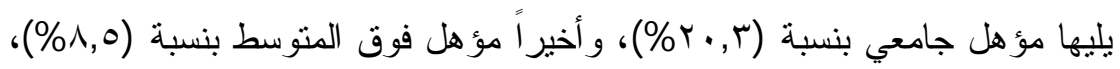

و هذا يشير الى توفر الخبر ات لدى الر ائدات الريفيات للتعامل مع المر أة الريفية.

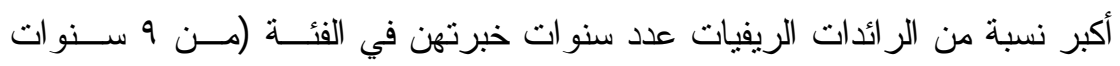

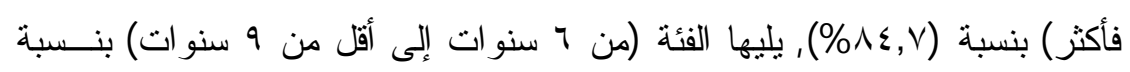

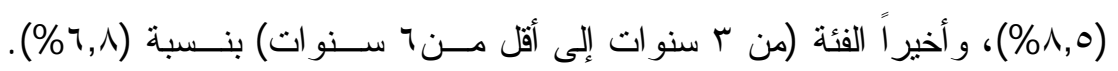

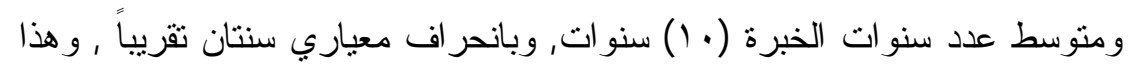

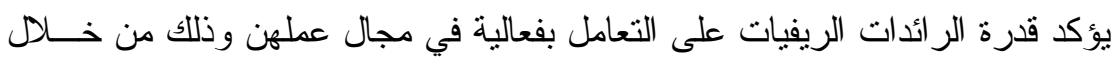

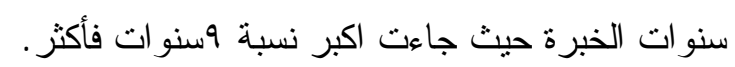

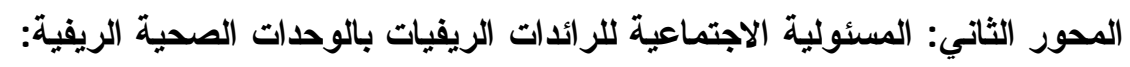

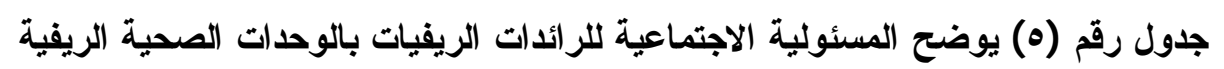

\begin{tabular}{|c|c|c|c|c|c|c|c|}
\hline \multicolumn{3}{|c|}{ الرائدات الريفيات (ن=99) } & \multicolumn{3}{|c|}{ المرأة الريفية (ن= ع (^) } & \multirow[b]{2}{*}{ العبارات } & \multirow[b]{2}{*}{$p$} \\
\hline الترتيب & المعياري & المسابي & الترتيب & المعباري & المسابي & & \\
\hline$r$ & צד, י & r,qV & $r$ & $\cdot, r \varepsilon$ & r,q & فههم الرية الئات الريفية لطيعة بالوحدات & 1 \\
\hline 1 & - & r & $\varepsilon$ & $\cdot, r$ & $r, q$ & 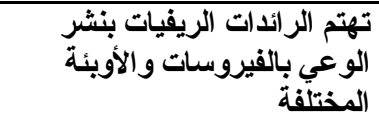 & $r$ \\
\hline 1 & . & $r$ & 1 & $\cdot, r$, & $r, 90$ & تكرين علاقات اجتماعية طيية ميع & $r$ \\
\hline 7 & ד & $r, r_{1}$ & $\wedge$ & r & $r, r v$ & تالتصدي اللرشكلات الريفية فية & $\varepsilon$ \\
\hline
\end{tabular}




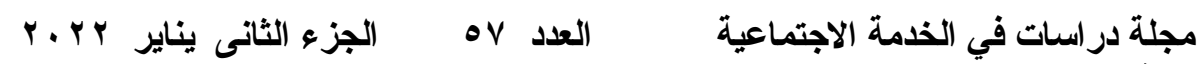
الموقع الاليكتروني:

\begin{tabular}{|c|c|c|c|c|c|c|c|}
\hline \multicolumn{3}{|c|}{ الرائدات الريفيات (ن=99) } & \multicolumn{3}{|c|}{ 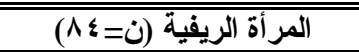 } & \multirow[b]{2}{*}{ العبار ات } & \multirow[b]{2}{*}{ e } \\
\hline الترتيب & المعياري & المستبط & الترتيب & المعياري & الحسابي & & \\
\hline 0 & $\cdot, \leqslant Y$ & $r, \wedge r$ & 9 & $\cdot, r q$ & $\curlyvee, \wedge \wedge$ & 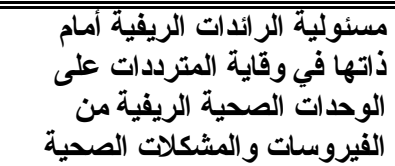 & 0 \\
\hline 1 & - & $r$ & $r$ & דוץ, & ץ,qu & 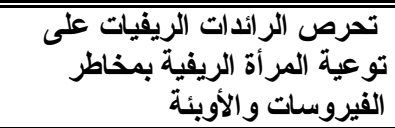 & 7 \\
\hline$\varepsilon$ & $\cdot, \leqslant 0$ & $r, \wedge 0$ & V & $\cdot, \pi \Lambda$ & ץ,А & 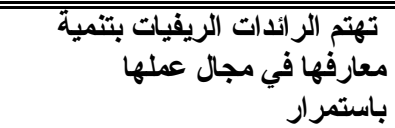 & $v$ \\
\hline$r$ & . ז & r,qu & • & . ז & ५,^৭ & 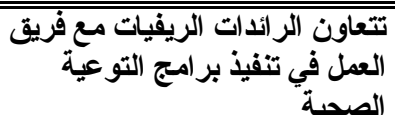 & $\wedge$ \\
\hline مرتفع & . & $r, q 1$ & مرتفع & $\cdot, 19$ & $\curlyvee, \wedge q$ & J & \\
\hline
\end{tabular}

يوضح الجدول السابق أن:

- مستوى المسئولية الاجتماعية للرائدات الريفيات بالوحدات الصحية الريفية كما تحددها المرأة الريفية مرتفع حيث بلغ المتوسط الحسابي (r,人9)، ومؤشرات ذلك وفقاً لتزتيب المتوسط الحسابي: الترنتب الأول تحرص الرائدات الريفية على تكوين علاقات اجتماعية طيبة مع الآخرين بمنوسط حسابي (Y,90), يليه التزتيب الثاني فهم الر ائدات

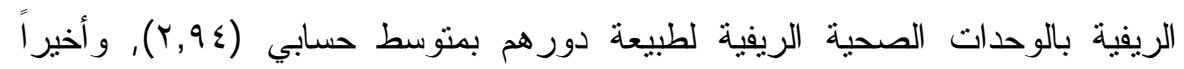
الترنيب الثامن تشارك الر ائدات الريفية في التصدي للمشكلات الصحية بمتوسط حسابي ويتفق ذلك مع دراسة عبد الله ( r,VV) المهارية للر ائدات الريفيات مثل مهارة إقامة علاقات اجتماعية ، وبناء القدر ات المعرفية للر ائدات الريفيات.

مستوى المسئولية الاجتماعية للر ائدات الريفيات بالوحدات الصحية الريفية كما تحددها الرائدات الريفيات مرتفع حيث بلغ المتوسط الحسابي (r,9))، ومؤشرات ذلك وفقاً لترنيب المتوسط الحسابي: الترنيب الأول تهنم الرائدات الريفيات بنشر الوعي بالفيروسات و الأوبئة المختلفة, وتحرص الرائدات الريفية على تكوين علاقات اجتماعية طيبة مع الآخرين بمتوسط حسابي (ب), يليه الترتيب الثاني فهم الرائدات الريفية بالوحدات الصحية الريفية لطبيعة دور هم بمنوسط حسابي (r,9V), و أخيراً الترنيب 


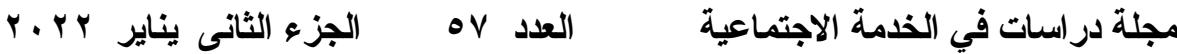

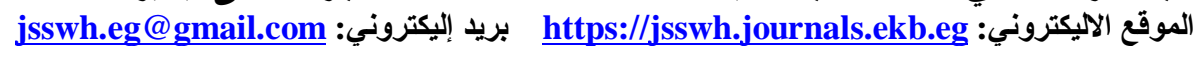

السادس تثارك الرائدات الريفية في التصدي للمشكلات الصحية بمتوسط حسابي

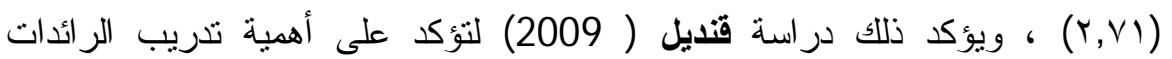

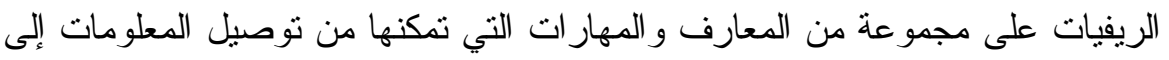

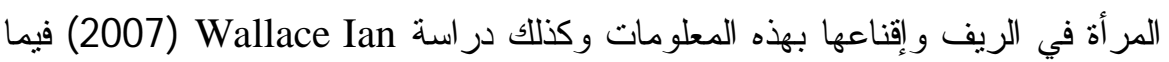

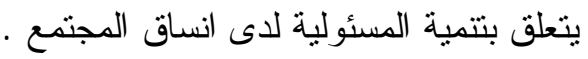

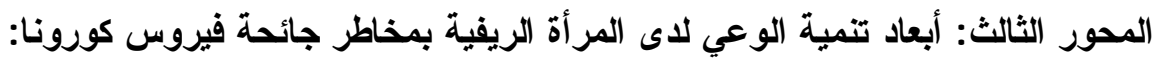

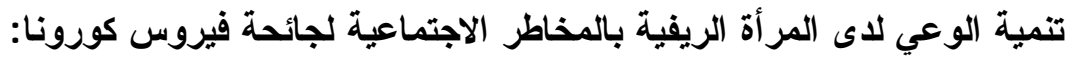
جدول رقم (ج) يوضح تنمية الوعي لاى المر أة الريفية بالمخاطر الاجتماعية لجائحة فيروس كورونا

\begin{tabular}{|c|c|c|c|c|c|c|c|}
\hline \multicolumn{3}{|c|}{ الرائدات الريفيات (ن=99) } & \multicolumn{3}{|c|}{ المر أة الريفية (ن=؛ ^^) } & \multirow[b]{2}{*}{ العبارات } & \multirow[b]{2}{*}{ a } \\
\hline | الترتيب & المعياري & الحستبي & 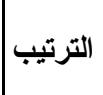 & المعياري & الحستوبي & & \\
\hline 1 & זי, & r, & 1 & • & $r, \mathrm{~V}$ & 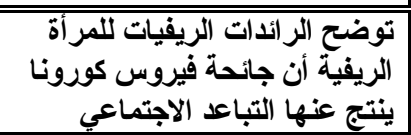 & 1 \\
\hline$\varepsilon$ & - , 9 & $1,9 \pi$ & $\varepsilon$ & • & $r, 1 \leqslant$ & 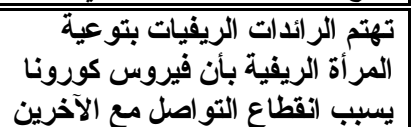 & r \\
\hline • & $\cdot, \wedge \mathrm{V}$ & $1, \mathrm{v}$, & $\mathrm{v}$ & $\cdot, \wedge \wedge$ & $1, \wedge 0$ & 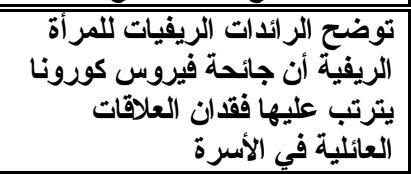 & $r$ \\
\hline 7 & $\cdot, \wedge \mu$ & 1, r & $\wedge$ & $\cdot, \wedge \wedge$ & $1, \Lambda r$ & 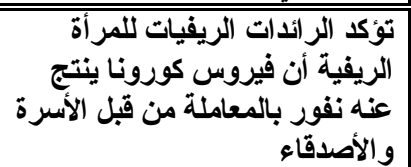 & $\varepsilon$ \\
\hline$\wedge$ & $\cdot, \wedge \varepsilon$ & 1,01 & 1 & $\cdot, 9 \mathrm{~V}$ & 1,90 & 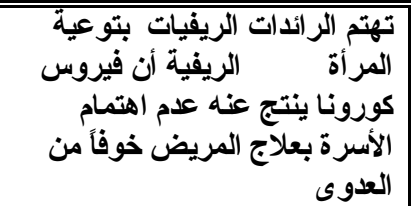 & 0 \\
\hline$r$ & -94 & $r, 10$ & $r$ & $\cdot, \mathrm{v}_{0}$ & $r, \varepsilon r$ & 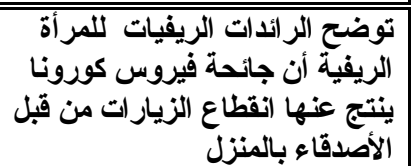 & 7 \\
\hline r & $\cdot, \mathrm{v}$ & $r, \leqslant 1$ & r & •, 0 & זיוצr & 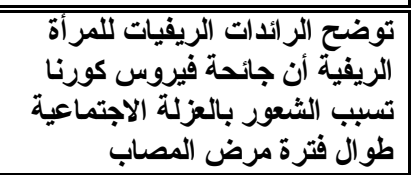 & v \\
\hline
\end{tabular}




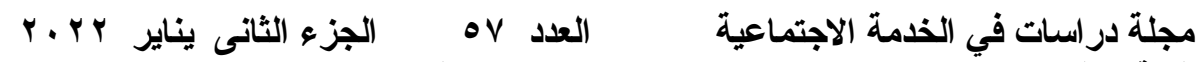

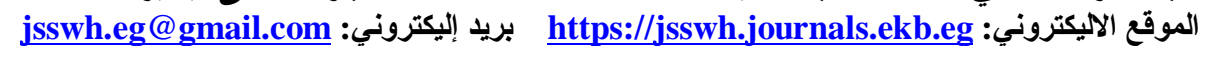

\begin{tabular}{|c|c|c|c|c|c|c|c|}
\hline \multicolumn{3}{|c|}{ الر ائدات الريفيات (ن=9 • ( } & \multicolumn{3}{|c|}{ 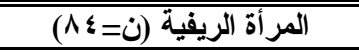 } & \multirow[b]{2}{*}{ العبار ات } & \multirow[b]{2}{*}{ b } \\
\hline الترتيب & المعياري & الحستوسي & الترتيب & المعياري & الحسابي & & \\
\hline$v$ & $\cdot, \wedge 9$ & 1,09 & 0 & $\cdot, \wedge 9$ & $r, 11$ & 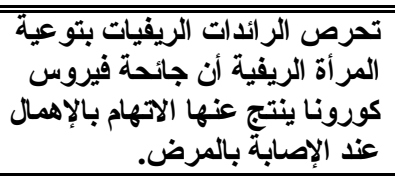 & $\wedge$ \\
\hline متستوى & $\cdot, \diamond \mathrm{V}$ & 1,90 & متوسطوى & $\cdot, 7$ & r, r & 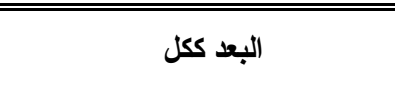 & \\
\hline
\end{tabular}

يوضح الجدول السابق أن:

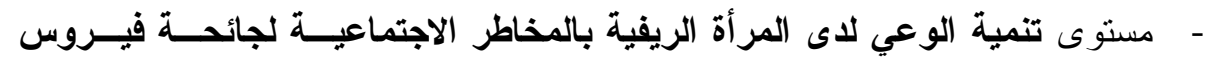

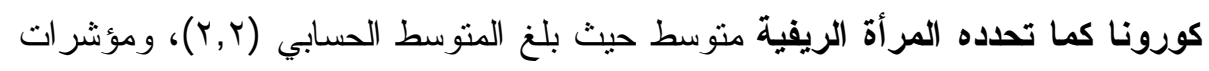

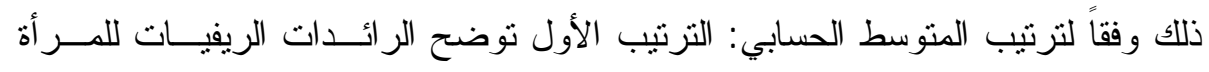
الريفية أن جائحة فيروس كورونا ينتج عنها التباعد الاجتماعي بمتوسط حسـسابي (Y,V),

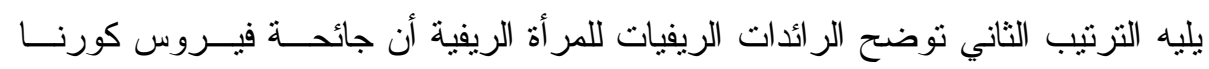

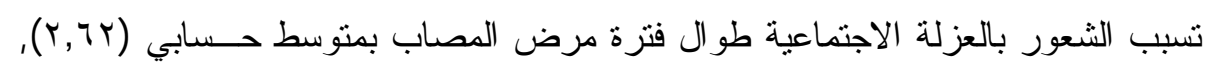

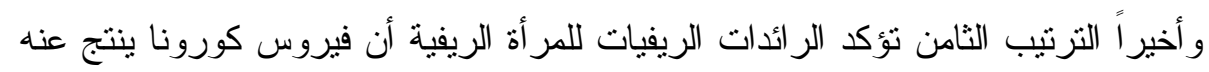
نفور بالمعاملة من قبل الأسرة و الأصدقاء بمتوسط حسابي (Y,A, I ) وهذا يتفــق ونتــائج در اسة Mustari\&Zebunnesa\&May (2020) و التي أكدت على انه يجب علـى بـى الجميع إتباع تعليمات الخبر اء في الحفاظ على التباعد الاجتماعي لتجنب فيروس كورونا .

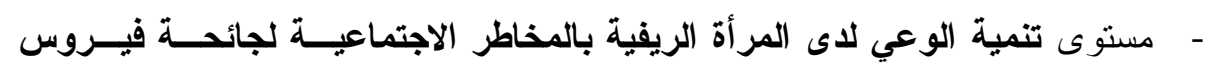

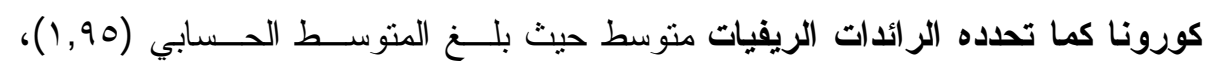

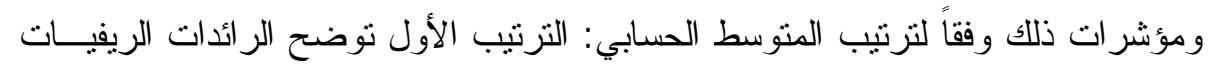
للمر أة الريفية أن جائحة فيروس كورونا ينتج عنها التباعد الاجتماعي بمتوســط حسـسابي

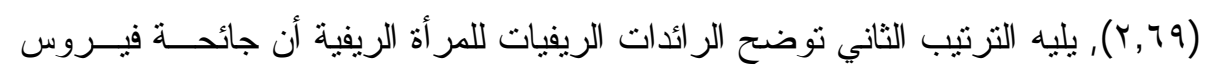
كورنا تسبب الثعور بالعزلة الاجتماعية طو ال فترة مرض المــصاب بمتوســط حـسابي

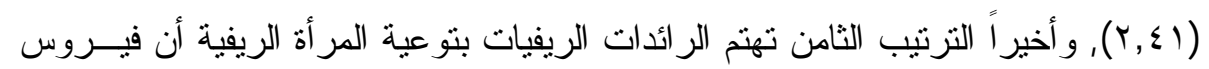
كورونا ينتج عنه عدم اهتمام الأسرة بعلاج المريض خوفاً من العدوى بمتوســط حـسـابي (1,01 (1, ) , وذذا يؤكد استجابات المبحوثين من الرائدات الريفيات حول تتمية وعى المــر أة الريفية بالمخاطر الاجتماعية لجائحة فيروس كورونا و التي جــاءت فــي الترتيــب الأول 
مجلة دراسات في الخدمة الاجتماعية الموقع الايكتروني:

تنمية الوعي لاى المرأة الريفية بالمخاطر الصحية لجائحة فيروس كورونا:

جلول رقم V) يوضح تنمية الوعي لاى المرأة الريفية بالمخاطر الصحية لجائحة فيروس كورونا

\begin{tabular}{|c|c|c|c|c|c|c|c|}
\hline \multicolumn{3}{|c|}{ الر ائدات الريفيات (ن=9 • } & \multicolumn{3}{|c|}{ المر أة الريفية (ن=ء ^^) } & \multirow[b]{2}{*}{ العبار ات } & \\
\hline & الآنحر افـ & المتوب & & الالحر افـ & المتوسد & & r \\
\hline Y & $\cdot, 71$ & $r, 7 \varepsilon$ & $\varepsilon$ & $\cdot, 71$ & $Y, 00$ & 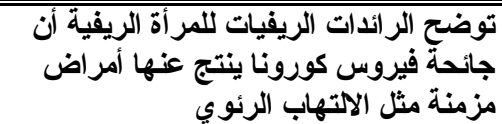 & 1 \\
\hline r & $\cdot, 71$ & $r, 7 \varepsilon$ & $r$ & $\cdot, \leqslant \Lambda$ & $Y, V_{1}$ & جائحة فيروس الر ائدات الريفيات للمر أة الريفية أن أندرية & r \\
\hline$\bullet$ & $\cdot, \wedge$ & $r, 19$ & 0 & $\cdot, 7 \varepsilon$ & $r, r V$ & 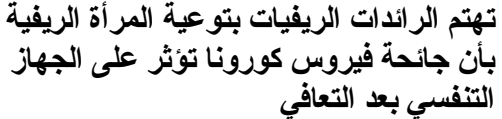 & $r$ \\
\hline$\varepsilon$ & $\cdot, V \varepsilon$ & r, rq & $r$ & $\cdot, 7 r$ & r, & 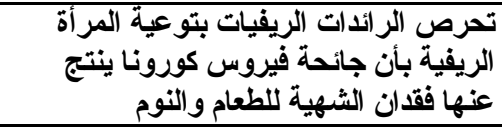 & $\varepsilon$ \\
\hline 7 & $\cdot, \wedge \bullet$ & $1, V_{1}$ & 7 & $\cdot, \Lambda \mu$ & $r, \cdot 1$ & 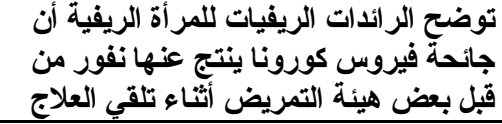 & $\bullet$ \\
\hline$r$ & $\cdot, \infty$ & Y, Yr & 1 & $\cdot, \mu V$ & $r, \wedge \mu$ & شائحة فيروس الر ائدات الريفيات للمر أة الريفية أن & 7 \\
\hline 1 & $\cdot, \leqslant V$ & 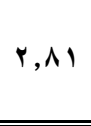 & 1 & $\cdot, r v$ & $r, \wedge \mu$ & 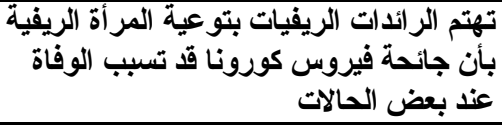 & V \\
\hline مستوى & $\cdot, r \varepsilon$ & $Y, \leqslant Y$ & مرتفتوى & • , & $Y, 0 Y$ & البعد ككل & \\
\hline
\end{tabular}

يوضح الجدول السابق أن:

- مستوى تنمية الوعي لاى المرأة الريفية بالمخاطر الصحية لجائحة فيروس كورونا كما

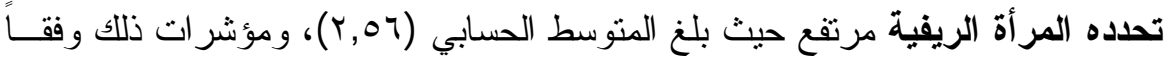

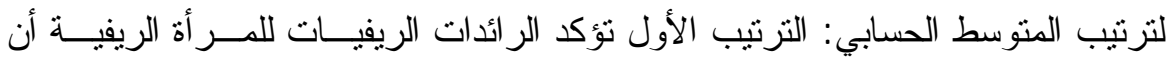

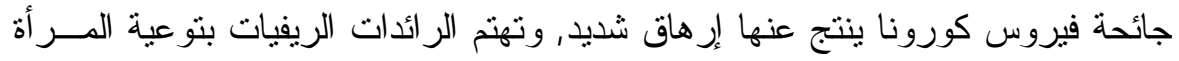

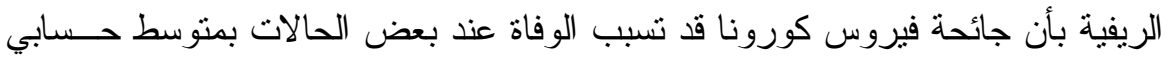

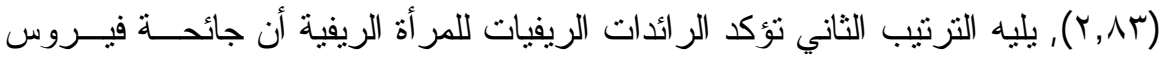

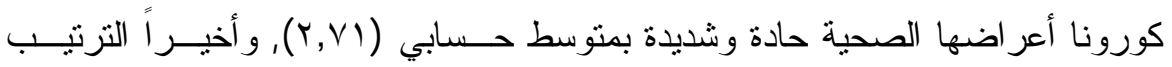

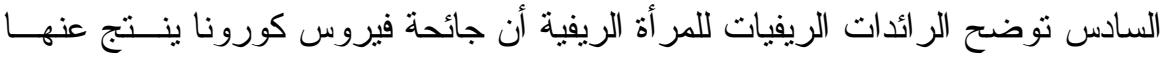




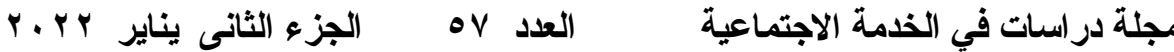
الموقع الاليكتروني:

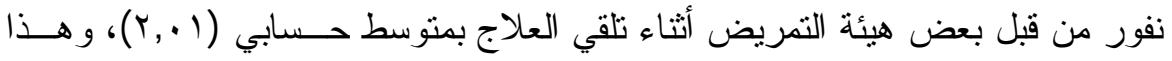
يثنير الى خطورة جائحة كورونا والتي لابد من اتخاذ كافة الإجراءات الصحية للوقايــة منه وضرورة قيام الر ائدات الريفيات بمسئولياتهم في توعية المر أة تجاه ذلك .

- مستوى تنمية الوعي لاى المرأة الريفية بالمخاطر الصحية لجائحة فيروس كورونا كما تحدده الرائدات الريفيات مرتفع حيث بلغ المتوسط الحسابي (r, ب)، ومؤشرات ذللك وفقاً لترتيب المتوسط الحسابي: الترتيب الأول تهنم الر ائدات الريفيــات بتوعيــة المــر أة الريفية بأن جائحة فيروس كورونا قد نسبب الوفاة عند بعض الحالات بمتوســ حـسابي

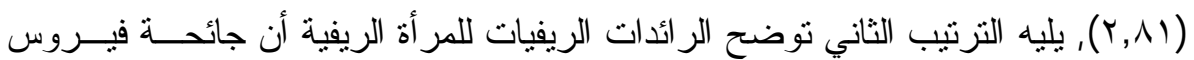

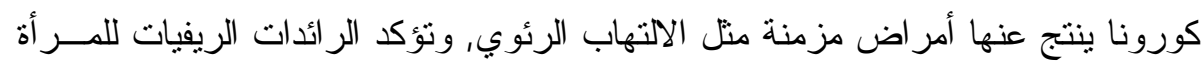

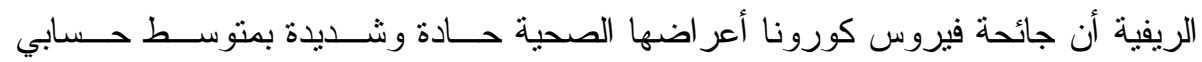

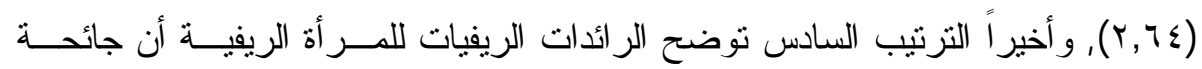
فيروس كورونا ينتج عنها نفور من قبل بعض هيئة التمريض أثناء تلقي العلاج بمتوســط

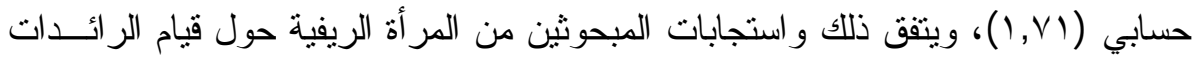
بدورهن في تتمية وعى المر أة الريفية بالمخاطر الصحية لفيروس كورونا.

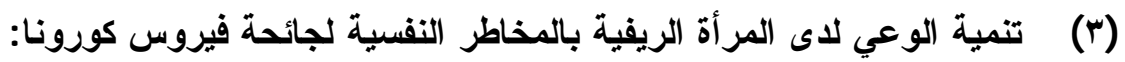
جدول رقم (^) يوضح تنمية الوعي لاى المرأة الريفية بالمخاطر النفسية لجائحة فيروس كورونا

\begin{tabular}{|c|c|c|c|c|c|c|c|}
\hline \multicolumn{3}{|c|}{ الرائدات الريفيات (ن=999) } & \multicolumn{3}{|c|}{ المر أة الريفية (ن= \& ^) } & \multirow[b]{2}{*}{ العبارات } & \\
\hline | الترتيب & الالمعياري اف & الحستوسي & |الترتيب|| & المعياري اف & الحستبي & & ? \\
\hline$r$ & $\cdot, \uparrow \wedge$ & $r, 01$ & $\varepsilon$ & $\cdot, 0 \leqslant$ & $r, \uparrow$ & 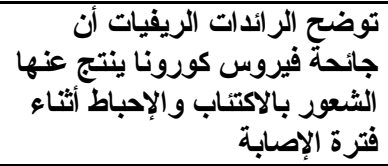 & 1 \\
\hline v & $\cdot, \wedge \varepsilon$ & 1,87 & $v$ & $\cdot, \wedge 0$ & $r, 11$ & 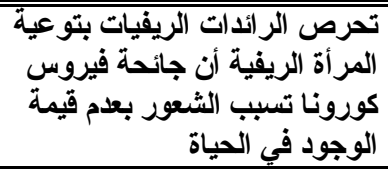 & $r$ \\
\hline 1 & • & r,q & 1 & $\cdot, 01$ & $Y, \vee Y$ & 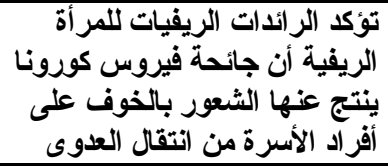 & $r$ \\
\hline 0 & $\cdot, \vee \vee q$ & $r, \cdot \Lambda$ & 7 & $\cdot, \wedge$ & $r, r V$ & 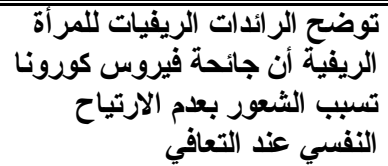 & \\
\hline
\end{tabular}




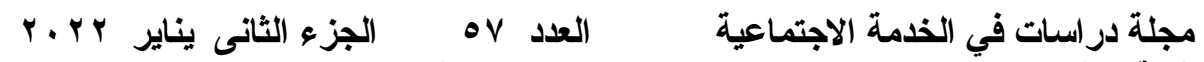

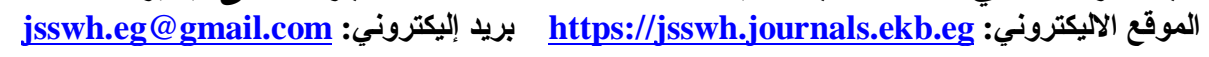

\begin{tabular}{|c|c|c|c|c|c|c|c|}
\hline \multicolumn{3}{|c|}{ الرائدات الريفيات (ن=99) } & \multicolumn{3}{|c|}{ المر أة الريفية (ن= \& (^) } & \multirow[b]{2}{*}{ 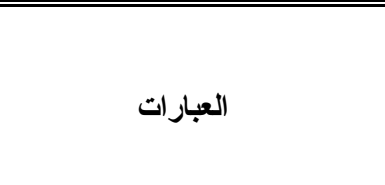 } & \multirow[b]{2}{*}{ b } \\
\hline | الترتيب & المعياري اف & الحستبي & الترتيب| & الالمياري & الحسابي & & \\
\hline ؛ & $\cdot, \mathrm{V}$ & $r, Y \leqslant$ & $r$ & •,Or & r, To & 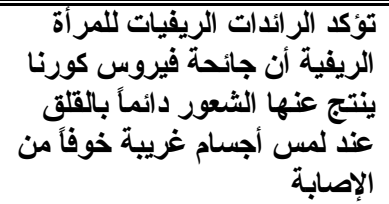 & 0 \\
\hline$r$ & $\cdot, v_{0}$ & $r, \& 1$ & r & $\cdot, \circ \mathrm{V}$ & $r, V r$ & 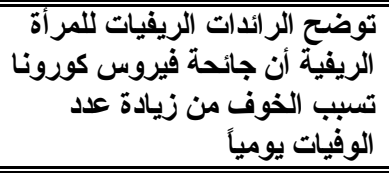 & 7 \\
\hline 7 & $\cdot, \wedge 1$ & $r$ & $\bullet$ & $\cdot, \vee \wedge$ & $r, \mu$ & 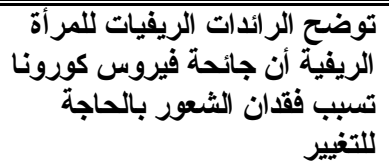 & $v$ \\
\hline متوستوى & $\cdot, \leqslant \leqslant$ & $r, r V$ & مرتفع & •, $\leqslant 7$ & $r, \leqslant q$ & 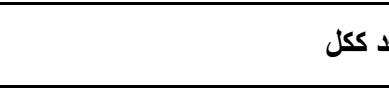 & \\
\hline
\end{tabular}

يوضح الجدول السابق أن:

- مستوى تنمية الوعي لاى المرأة الريفية بالمخاطر النفسية لجائحة فيروس كورونا كما

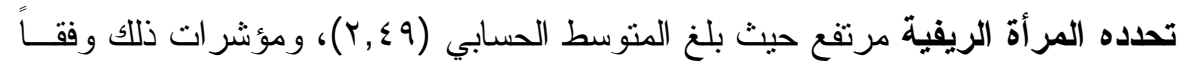

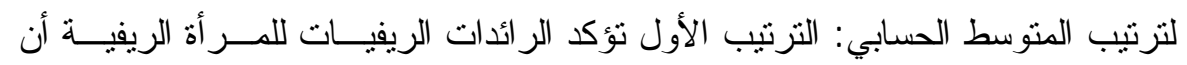

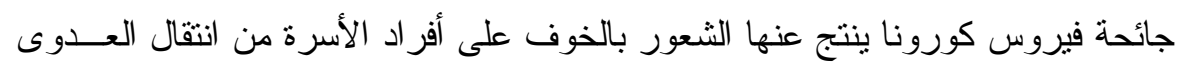

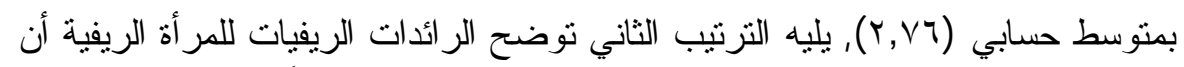

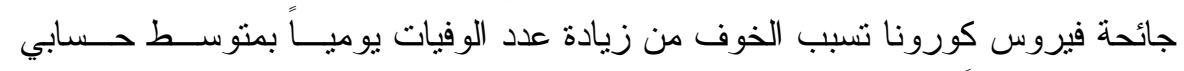
جائحة (Y,VT)

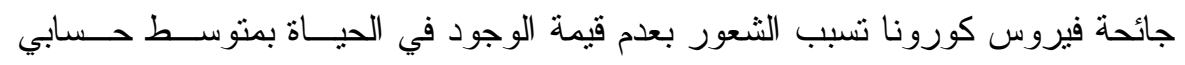

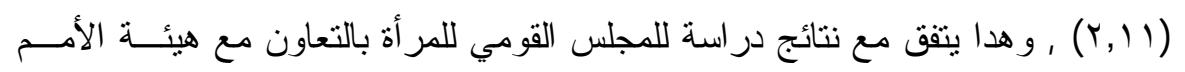

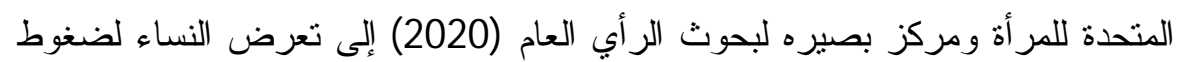

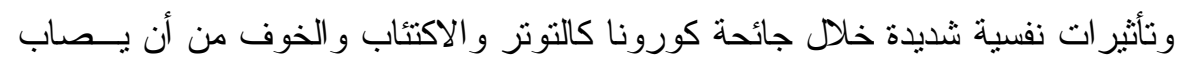

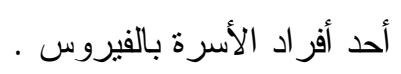

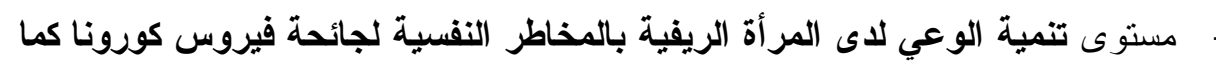

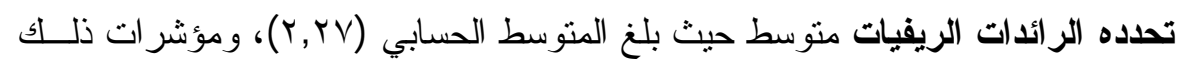

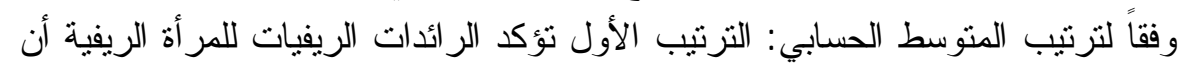

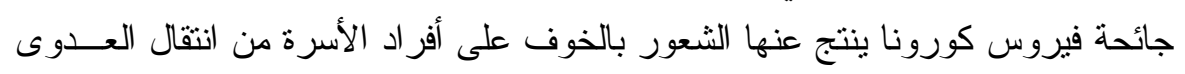

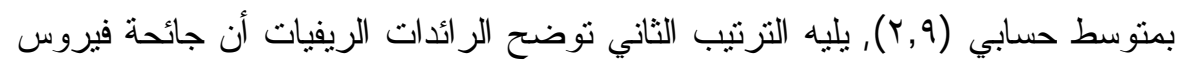




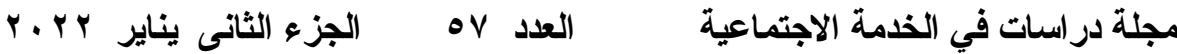
الموقع الايكتروني:

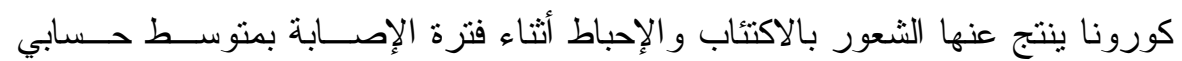

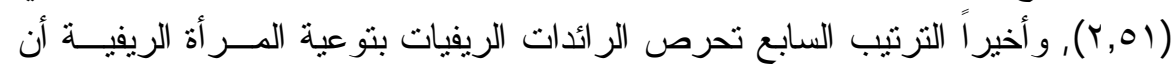

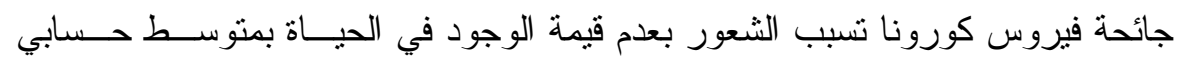

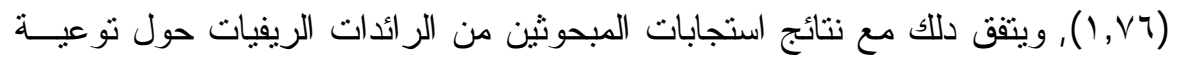

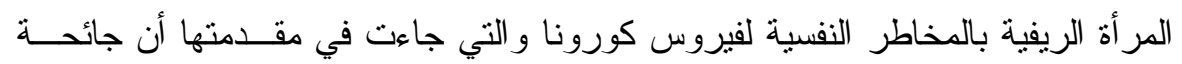

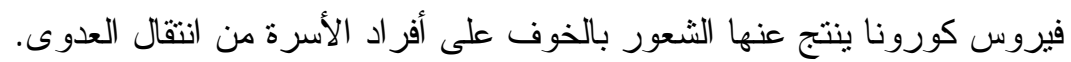

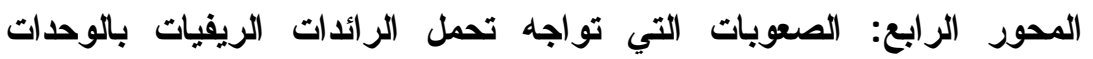
الصحية المسئولية الاجتماعية في تنمية الوعي لدى المرأة الريفية بمخاطر جائحة

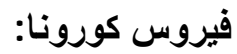

جدول رقم (9) يوضح الصعوبات التي تواجه تحمل الرائدات الريفيات بالوحدات الصحية

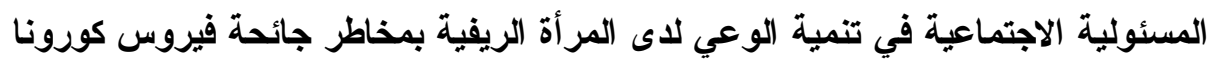

\begin{tabular}{|c|c|c|c|c|c|c|c|}
\hline \multicolumn{3}{|c|}{ الر ائدات الريفيات (ن=99) } & \multicolumn{3}{|c|}{ المر أة الريفية (ن=ء (^) } & \multirow[b]{2}{*}{ العبارات } & \multirow[b]{2}{*}{$P$} \\
\hline 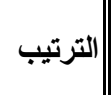 & المعياري & المسابي & | الترتيب & المعياري & | الصتابي & & \\
\hline$r$ & $\cdot, v_{1}$ & ץ & 1 & •, & $r, v r$ & النقلامة الإمكانيات بالألمالية & 1 \\
\hline$r$ & $\cdot, v$ & r,YY & $r$ & •, & צו, & التفراضة الريفية المستوى التعليمي & $r$ \\
\hline$\varepsilon$ & ו & 1,94 & 9 & $\cdot, \Lambda$ & 1,70 & الريعوبة التعامل مع الر ائدات & 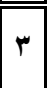 \\
\hline 1 & 14, • & r, 79 & $\wedge$ & • & $1, \mathrm{~V}$ & 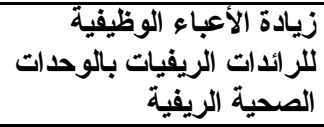 & $\varepsilon$ \\
\hline v & $\cdot, \wedge$ & 1,14 & 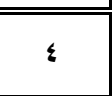 & ד & $1,9 \leqslant$ & صالنسبة للمر ألة الرئد الريفيات & 0 \\
\hline . & •, ^० & $1, \wedge 0$ & 1. & $\cdot, \wedge \mathrm{V}$ & $1,1 \leqslant$ & بالدوحات الرائدات الريفية الريفية & 1 \\
\hline 1 & •, ^० & $1, \wedge 0$ & $r$ & • & $r, r$ & بالويفيات وفريق التعاون بين الرلائدات & $v$ \\
\hline$\wedge$ & $\cdot, \vee \vee \varepsilon$ & $1, r q$ & 7 & • Ar & $1, \times 4$ & كوراطر جائحة فيروس برون التوعية & $\wedge$ \\
\hline | متوستط & •, ro & $1,9 \leqslant$ & متوستوى مستو & ,, $0 \leqslant$ & 1,94 & البعد ككل & \\
\hline
\end{tabular}




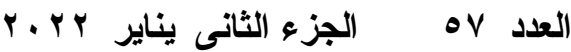

مجلة در اسات في الخدمة الاجتماعية

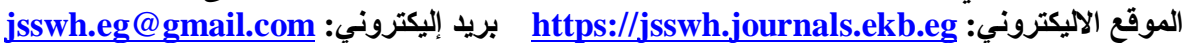

\section{يوضح الجدول السابق أن:}

- مستوى الصعوبات التي تواجه تحمل الرائدات الريفيات بالوحدات الصحية المسئولية الاجتماعية في تنمية الوعي لاى المرأة الريفية بمخاطر جائحة فيروس كورونا كما تحددها المرأة الريفية متوسط حيث بلغ المنتسط الحسابي (79, 1)، ومؤشرات ذلكيه وفقاً لترتيب المتوسط الحسابي: الترنيب الأول نقص الإمكانيات المالية اللازمة للقيام بالأنشطة المطلوبة للتوعية بمتوسط حسابي (Y,VT), يليه التزتيب الثاني انخفاض

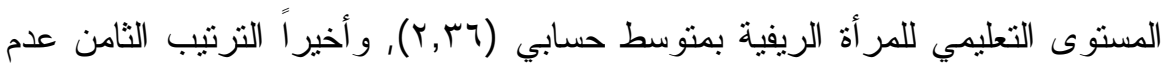
وضوح برنامج التوعية بمخاطر جائحة فيروس كورونا بمنوسط حسابي ( T,VI))، وينفق ذلك ودر اسة محمود (1993) و التي توصلت إلى أن هناك قصور في برامج خدمات التقيف الصحي بالوحدة الصحية الريفية ، وكذللك قصور في الإمكانيات المادية لخدمات مكافحة الأمراض المستوطنة و المعدية في القرية ، و أيضا دراسة ماريت ستانتون Marietta Stanton (2009) و التي أشنارت الى أن تحسين نوعية الرعاية الصحية تأتى بالتعليم واستخدام تقنيات حديثة لاعم الرعاية الصحية ، وأيضا دراسة دراسة حسن (2015) والتي استهدفت تحديد المعوقات التي تواجه الوحدة الصحية الريفية و أثنارت نتائجها أن هذه المعوقات مرتبطة بالإمكانيات المادية البشرية بالوحدة الصحية الريفية.

مستوى الصعوبات التي تواجه تحمل الرائدات الريفيات بالوحدات الصحية المسئولية الاجتماعية في تنمية الوعي لاى المرأة الريفية بمخاطر جائحة فيروس كورونا كما تحددها الرائدات الريفيات منوسط حيث بلغ المتوسط الحسابي ( 9 ( ) )، ومؤشرات ذللك وفقاً لترتيب المتوسط الحسابي: الترتيب الأول زيادة الأعباء الوظيفية للرائدات الريفيات بالوحدات الصحية الريفية بمنوسط حسابي (r,79), يليه الترنيب الثاني نقص الإمكانيات

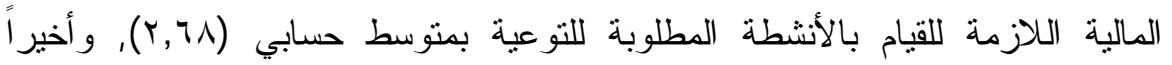
الترتيب الثامن عدم وضوح برنامج التوعية بمخاطر جائحة فيروس كورونا بمنوسط حسابي (q ب, (1) ، ويؤكد ذلك نتائج المبحوثين من المر أة الريفية مما يستوجب ضرورة توفير الإمكانيات المادية اللازمة للقيام بأنشطة التوعية الصحية حيث أكدت دراسة ماريت ستانتون Marietta Stanton (2009) تحسين نوعية الرعاية الصحية تأتى بالتعليم واستخدام تقنيات حديثة لاعم الرعاية الصحية ولن يتحقق ذلك الإ عن طريق توفير الإمكانيات المادية اللازمة لذلك. 


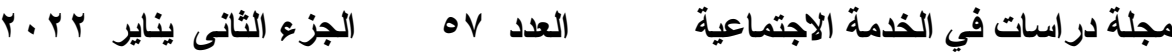

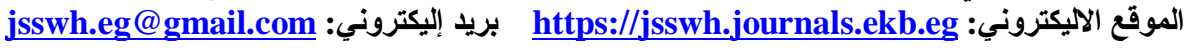

المحور الخامس: مقترحات تفعيل المسئولية الاجتماعية للرائدات الريفيات بالوحدات الصحية في تنمية الوعي لاى المرأة الريفية بمخاطر جائحة فيروس كورونا: يوضح جلول رقم (· (1) مقترحات تفعيل المسئولية الاجتماعية للرائدات الريفيات بالوحدات الصحية في تنمية الوعي لاى المرأة الريفية بمخاطر جائحة فيروس كورونا

\begin{tabular}{|c|c|c|c|c|c|c|c|}
\hline \multicolumn{3}{|c|}{ الر ائدات الريفيات (ن=9 ه) } & \multicolumn{3}{|c|}{ 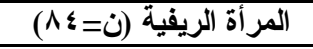 } & \multirow[b]{2}{*}{ العبار ات } & \multirow[b]{2}{*}{ r } \\
\hline إ) & الآحر افـ & المتوسد & آت ت & الاتحر (فـ & المتوسط & & \\
\hline V & $\cdot, 7 \wedge$ & $\curlyvee, 7 \wedge$ & 7 & $\cdot, \bullet \wedge$ & $r, 79$ & ضائحة فيروس وضوح كورونامتج التوعية بمخاطر & 1 \\
\hline 1 & • & $r, q$ & $\Lambda$ & • & Y, $7 \varepsilon$ & 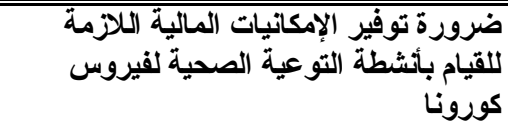 & $r$ \\
\hline$r$ & $\cdot, \leqslant \Lambda$ & $Y, \wedge \bullet$ & $\varepsilon$ & $\bullet, 07$ & $r, V_{0}$ & 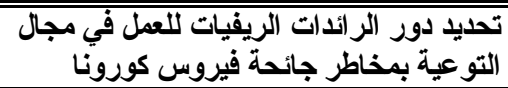 & $r$ \\
\hline$Y$ & •, \{ & $r, q$ & $Y$ & .,Or & $Y, \vee q$ & توفير الرائدات الريفيات المادي والمعنوي للمر أة الريفية & $\varepsilon$ \\
\hline$\varepsilon$ & $\cdot, \leqslant 7$ & $r, \vee \wedge$ & 1 & $\cdot, \varepsilon r$ & $\curlyvee, \wedge \wedge$ & في إكساب التر ائدات الريفيات بمخاطر فيروس كورونا المهات اللازمة & 0 \\
\hline 0 & $\cdot, 7 \varepsilon$ & $r, V_{1}$ & V & $\bullet, 0 \leqslant$ & Y, ४ & 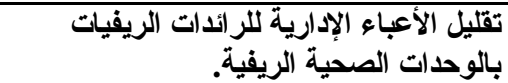 & V \\
\hline$\Lambda$ & $\cdot, \mathrm{VI}$ & $Y, 74$ & 0 & $\bullet, \diamond \wedge$ & $r, V$ & 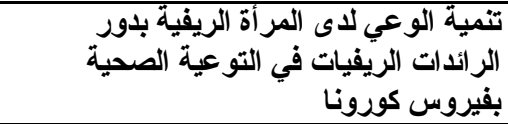 & 9 \\
\hline 7 & $\cdot, 7 \wedge$ & $7,7 q$ & $r$ &., 01 & $Y, V Y$ & 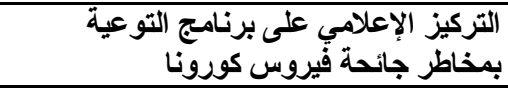 & 1. \\
\hline مرتفع مستوى & •, & $r, V Y$ & مرتفع مستوى & $\cdot, \leqslant$ & $r, v r$ & البعد ككل & \\
\hline
\end{tabular}

يوضح الجدول السابق أن:

مستوى مقترحات تفعيل المسئولية الاجتماعية للرائدات الريفيات بالوحدات الصحية

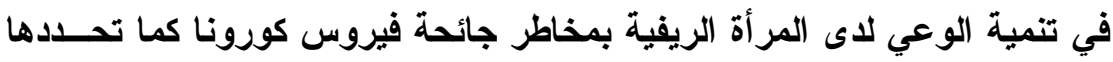

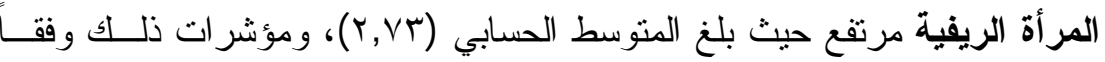

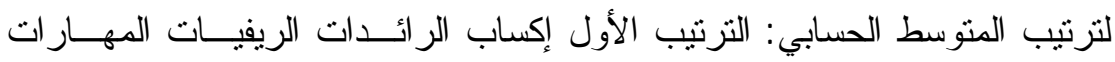

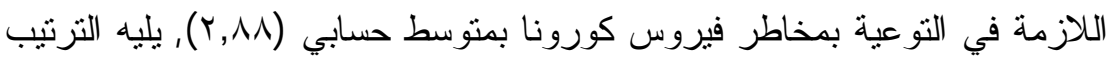

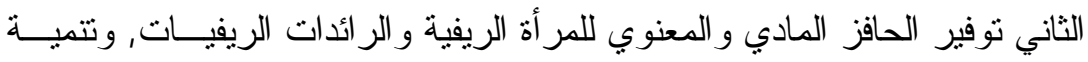

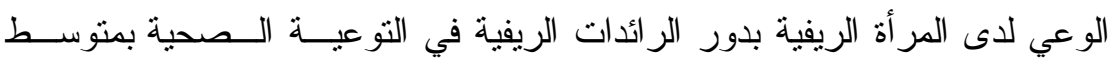

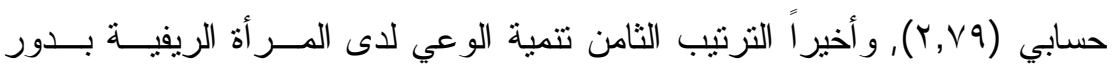




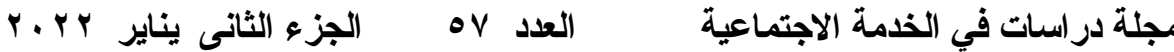

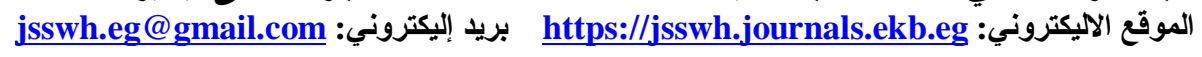

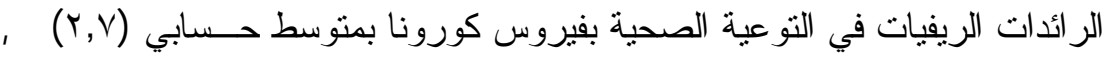
و هذا يثير الى وجود معوقات وصعوبات تتطلب الحد منهــا فـي ســبيل تفعيـل

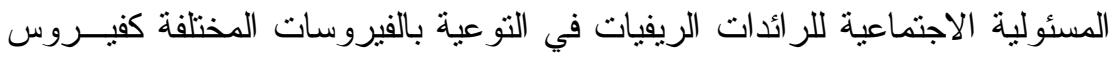

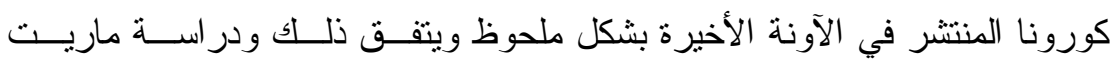

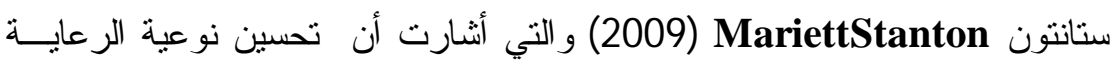

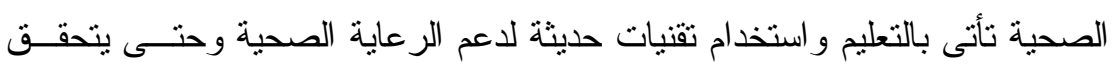
ذلك لابد من نوفير الإمكانيات المادية اللازمة لذلك.

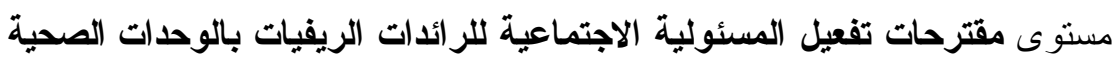

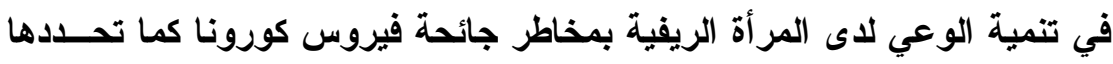

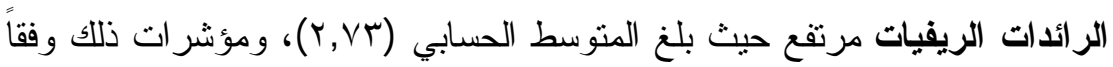

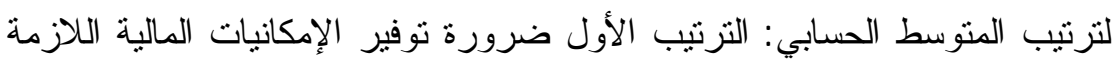

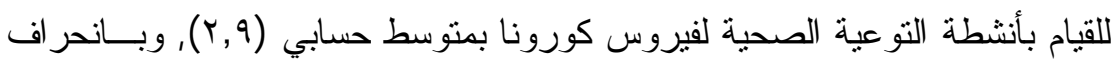

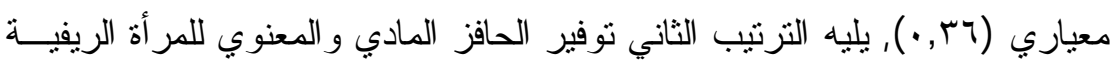

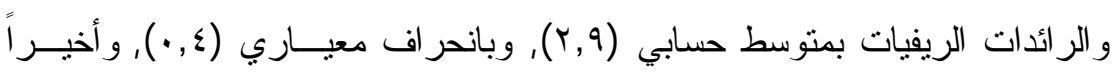

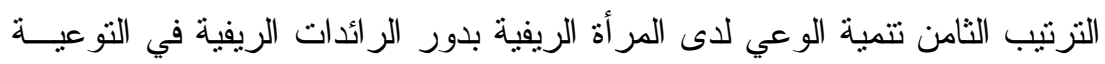

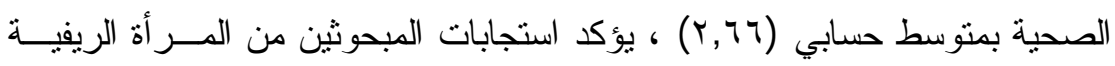

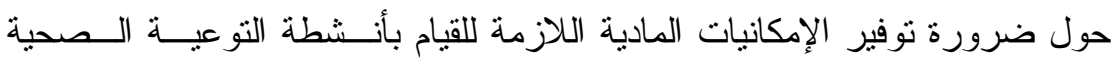

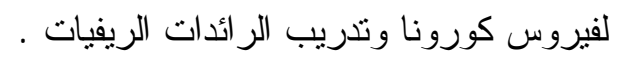

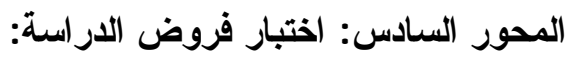

(ع) اختبار الفرض الأول للارسة: " من المتوقع أن يكون مستوى المسئولية

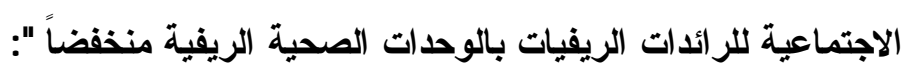

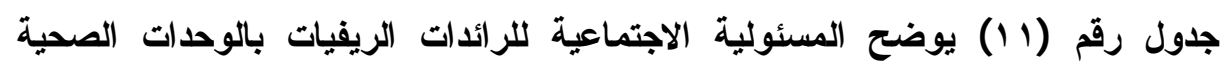

\begin{tabular}{|c|c|c|c|c|c|c|}
\hline \multicolumn{3}{|c|}{ الر ائدات الريفيات (ن=99) } & \multicolumn{3}{|c|}{ المر أة الريفية (ن=ء ع) } & \multirow[b]{2}{*}{ العبارات } \\
\hline الترتيب & الالاحعراف & الحستوسط & الترتيب & المعياري & الحستابي & \\
\hline مرتفتى & 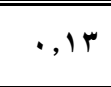 & r,q & مرتفع مي & $\cdot, 19$ & $r, \wedge q$ & اللرائدات الريفية الاجتماتية كلية \\
\hline
\end{tabular}




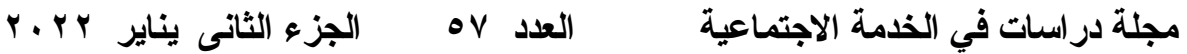

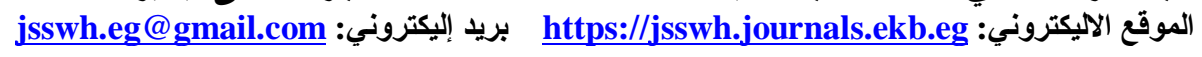

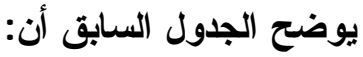

المتوسط العام للمسئولية الاجتماعية للرائدات الريفيات بالوحدات الصحية الريفية

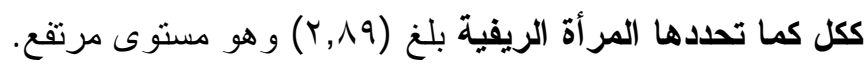

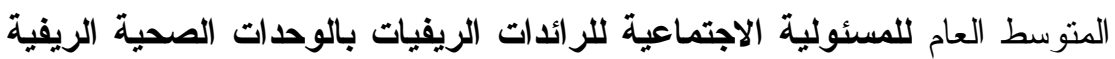

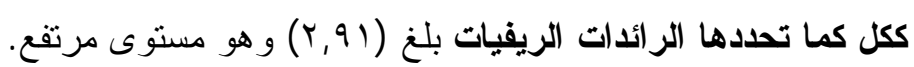

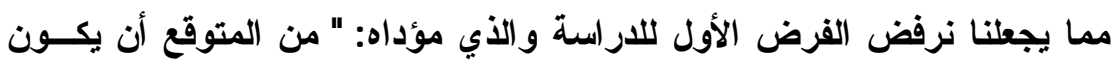

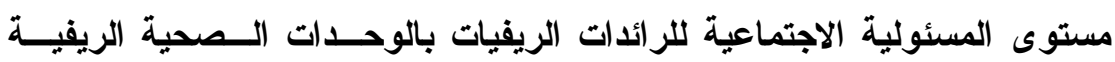

\section{منخفضاً.}

اختبار الفرض الثاني للاراسة:" من المتوقع أن يكون مستوى تتمية الوعي لدى

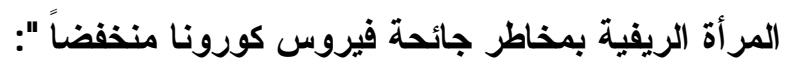

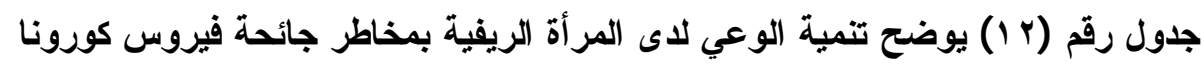

\begin{tabular}{|c|c|c|c|c|c|c|c|}
\hline \multicolumn{3}{|c|}{ الر ائدات الريفيات (ن=99) } & \multicolumn{3}{|c|}{ المر أة الريفية (ن=ء ^^) } & \multirow[b]{2}{*}{ 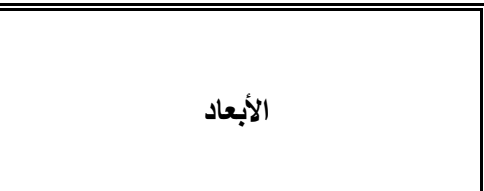 } & \multirow[b]{2}{*}{ 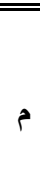 } \\
\hline |الترتيب & الالاحعراري & |الحستوسطي ||ل||| & | الترتيب|| & المعياري & الحستابي & & \\
\hline$r$ & $\cdot, \Delta \mathrm{V}$ & 1,90 & $r$ & $\cdot, 7$ & $r, r$ & 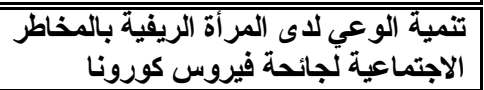 & 1 \\
\hline 1 & $\cdot, r \leq$ & $r, \leqslant r$ & 1 & • & Y,0 & 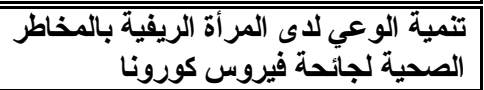 & r \\
\hline r & $\cdot, \leq \leqslant$ & r, rV & r & 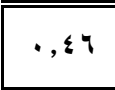 & $r, \leqslant q$ & 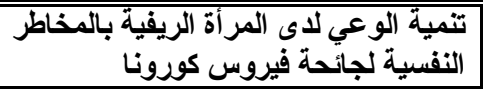 & $r$ \\
\hline متوستوى & •, tro & r, r & | مستفوى | مرتو | مستو & $\cdot, \leqslant$, & $r, \leqslant Y$ & أبعاد تنمية الوعي ككل & \\
\hline
\end{tabular}

مستوى أبعاد تنمية الوعي لدى المرأة الريفية بمخاطر جائحة فيروس كورونا ككل

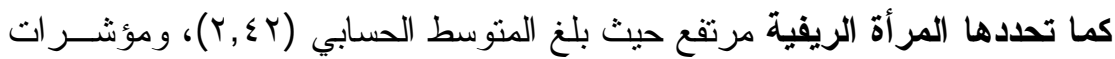

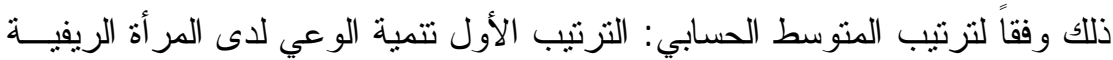

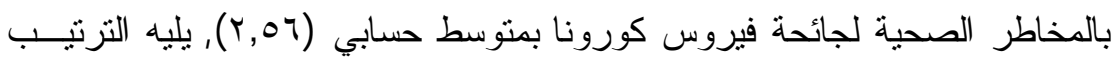

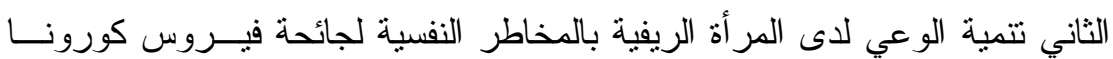

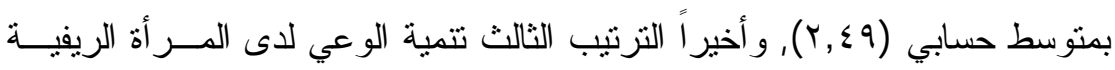

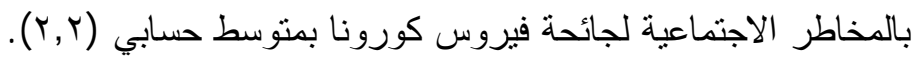




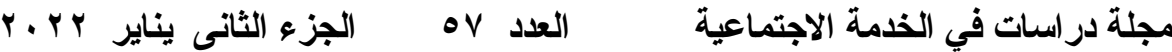

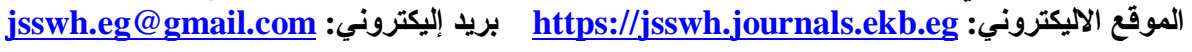

مستوى أبعاد تنمية الوعي لاى المرأة الريفية بمخاطر جائحة فيروس كورونا ككل

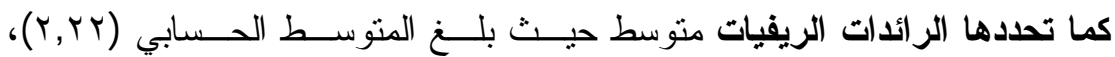

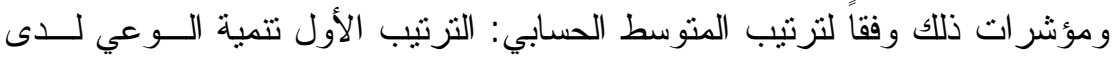

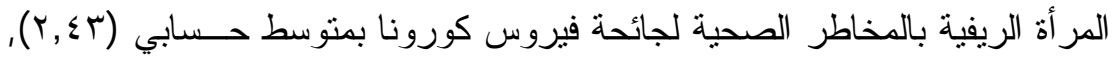

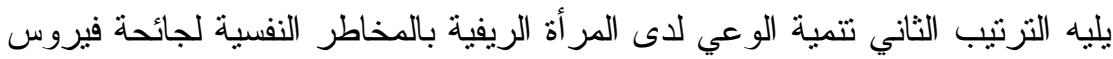

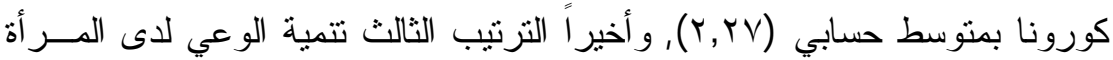

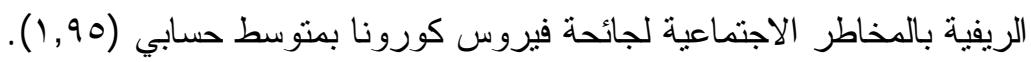

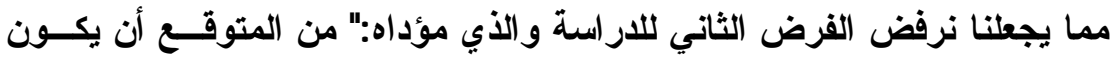

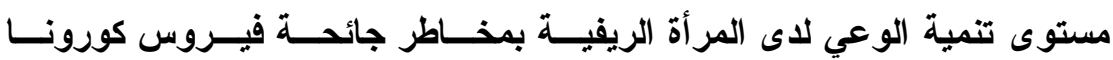
منذفضاً".

اختبار الفرض الثالث للاراسة:" توجد علاقة طردية دالة إحصائياً بين المسئولية الاجتماعية للرائدات الريفيات بالوحدات الصحية وتنمية الوعي لاى المر أة الريفية

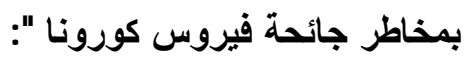

جدول رقم (ب ا) يوضح تحليل الاحدار البسيط للعلاقة بين المسئولية الاجتماعية للرائدات

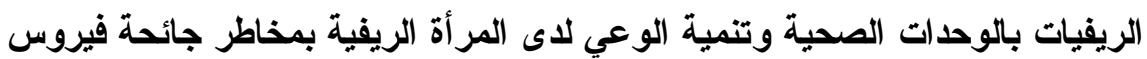

كورونا

\begin{tabular}{|c|c|c|c|c|c|c|c|}
\hline $\begin{array}{l}\text { التحديد } \\
\mathbf{R}^{2} \\
\end{array}$ & $\begin{array}{c}\text { الارتباط } \\
\mathbf{R} \\
\end{array}$ & 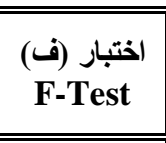 & $\begin{array}{c}\text { (تثتبار } \\
\text { T-Test } \\
\end{array}$ & $\begin{array}{c}\text { الاحدارا } \\
\text { B } \\
\end{array}$ & ن & البحثم & المتغيرات المستقلة \\
\hline$\cdot, .79$ & *, & $* \theta, r \leq$. & $* Y, .09$ & $\cdot, r \cdot 1$ & $\Lambda \varepsilon$ & مرأة مر & \multirow{2}{*}{ المسئولية الاجتماعية للراندات } \\
\hline 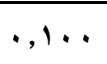 & **., & $* * \cdot, q, \wedge \wedge$ & $* * \%, .1 \leqslant$ & r.794. & 09 & رائدات & \\
\hline
\end{tabular}

$$
\text { * مغنوي عذ (., ) }
$$

$$
\begin{aligned}
& \text { ** معنوي غند (1, , . ) } \\
& \text { يوضح الجدول السابق أن: }
\end{aligned}
$$

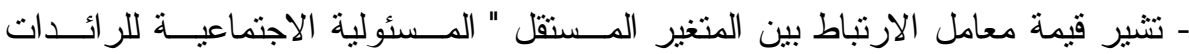

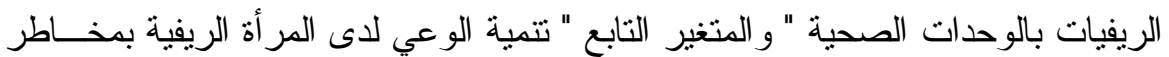

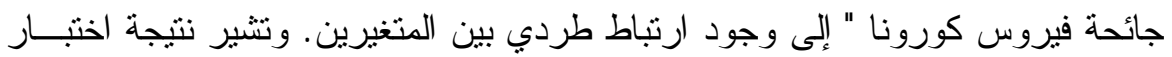

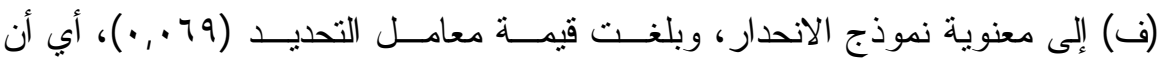

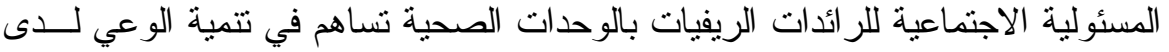

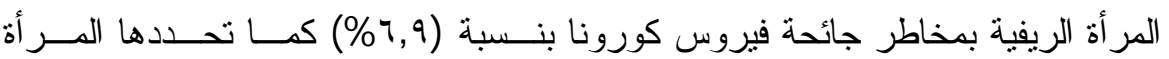




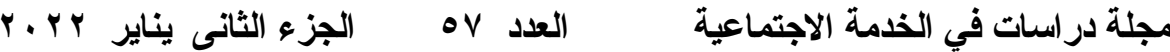
لبوقع الاليكتروني: https://jsswh.journals.ekb.eg بريد إليكتروني: jsswh.eg@gmail.com

ـ تثير قيمة معامل الارنباط بين المتغير المـستقل " المـسئولية الاجتماعيـة للرائـدات

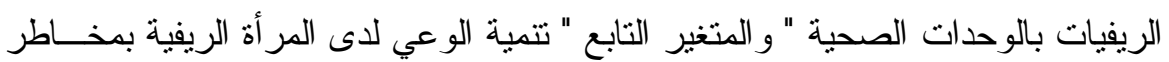
جائحة فيروس كورونا " إلى وجود ارتباط طردي بين المتغيرين ـونتير نتيجة اختبـار

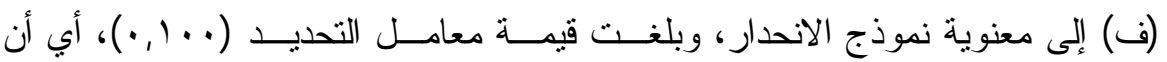

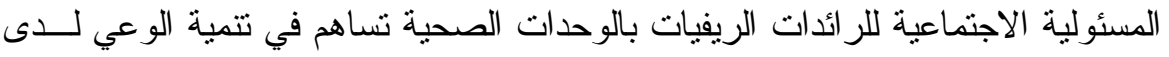

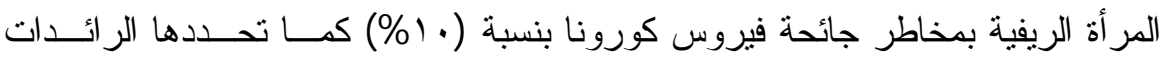

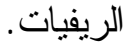

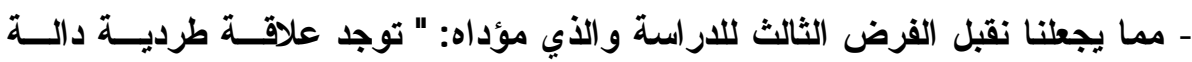

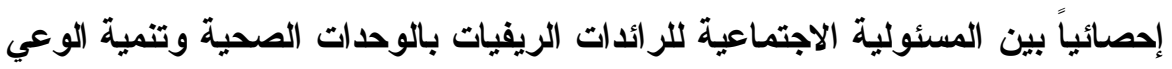

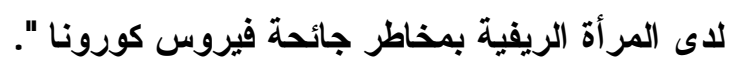

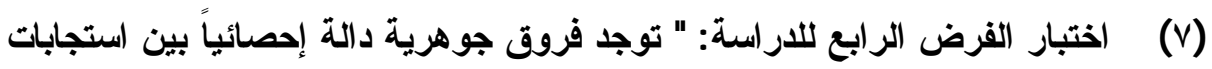

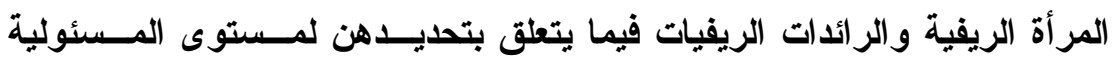
الاجتماعية للرائدات الريفيات بالوحدات الصحية ":

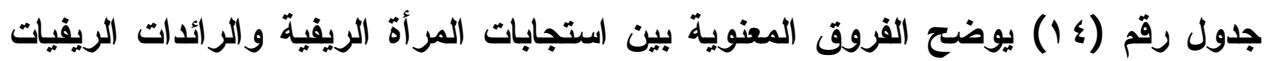
فيما يتعلق بتحديدهن لمستوى المسئولية الاجتماعية للرائدات الريفيات بالوحدات الصحية لئه

\begin{tabular}{|c|c|c|c|c|c|c|c|}
\hline الالالاة & قيمة T" & $\begin{array}{l}\text { الحرجية ( } \\
\text { ( df) }\end{array}$ & المعياري & الحسابي & العداد (ن) & البحتمّ & الأبعاد \\
\hline \multirow{2}{*}{ غال } & \multirow{2}{*}{, $\bar{i} \wedge v$} & \multirow{2}{*}{$1 \leqslant 1$} & 0.19 & $r, \wedge 9$ & $\overline{\Lambda \Sigma \varepsilon}$ & مرأة & \multirow{2}{*}{ لاجتماعية للزئلداتدات } \\
\hline & & & r & r,q) & $\Delta q$ & راندات & \\
\hline
\end{tabular}

$$
\text { يوضح الجدول السابق أن: }
$$

لا توجد فروق جوهرية دالة إحصائياً بين استجابات المرأة الريفية والرائدات

الريفيات فيما يتعلق بتحديدهن لمستوى المسئولية الاجتماعية للرائدات الريفيات بالوحدات

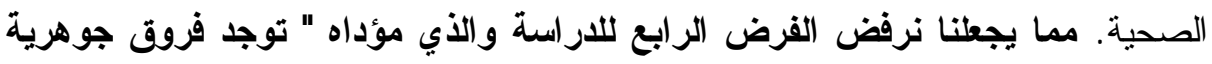

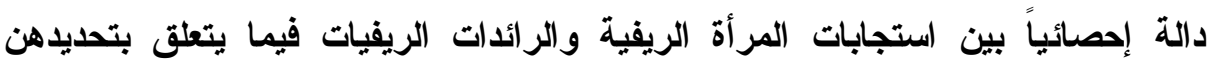

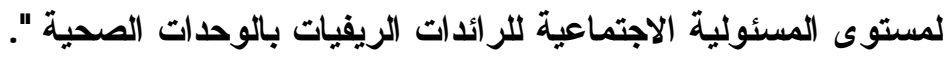




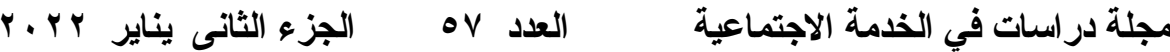

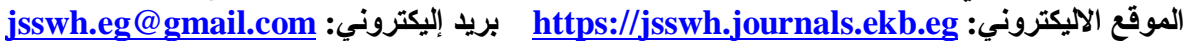

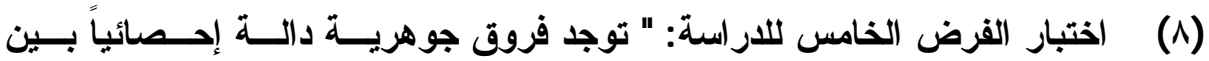

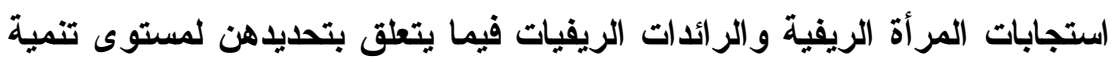
الوعي لاى المرأة الريفية بمخاطر جائحة فيروس كورونا ":

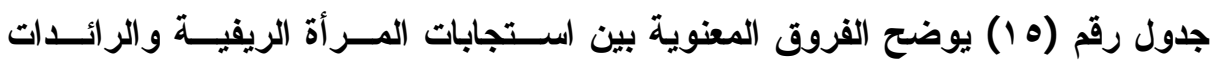
الريفيات فيما يتعلق بتحديدهن لمستوى تنمية الوعي لاى المرأة الريفية بمخاطر جائحة

$$
\begin{aligned}
& \text { * مغنوي عند (.0,. ) } \\
& \text { ** منوي غذ (1 ., . ) } \\
& \text { يوضح الجدول السابق أن: }
\end{aligned}
$$

- نوجد فروق جوهرية دالة إحصائياً عند مستوى معنوية (0.,. •) بين استجابات المرأة الريفية والرائدات الريفيات فيما يتعلق بتحديدهن لمستوى تتمية الوعي لاى المرأة

الريفية بالمخاطر الاجتماعية لجائحة فيروس كورونا لصالح استجابات المر أة الريفية.

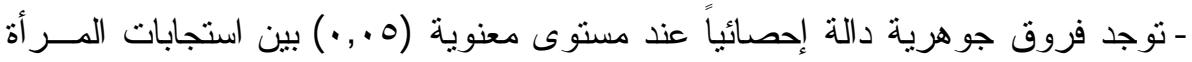

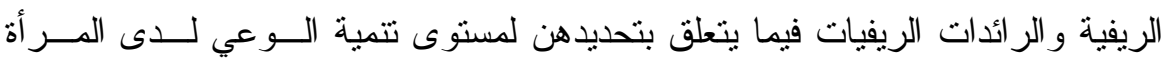
الريفية بالمخاطر الصحية لجائحة فيروس كورونا لصالح استجابات المر أة الريفية.

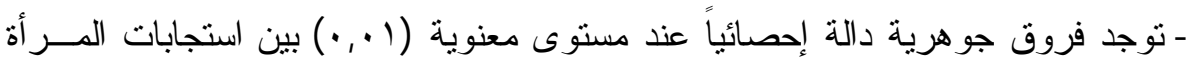

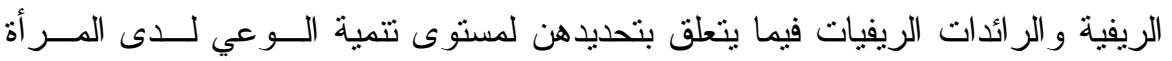

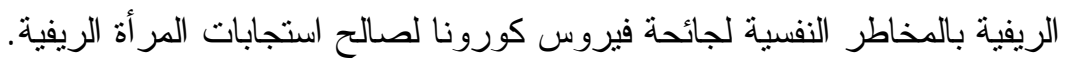

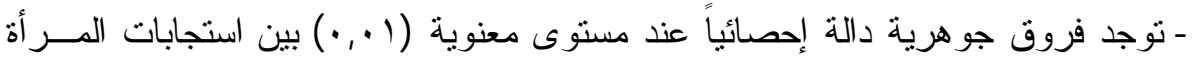

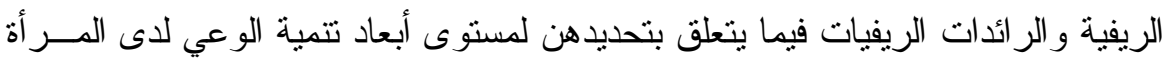
الريفية بمخاطر جائحة فيروس كورونا ككل لصالح استجابات المر أة الريفية. 


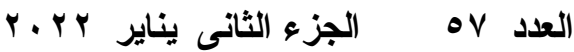

مجلة در اسات في الخدمة الاجتماعية

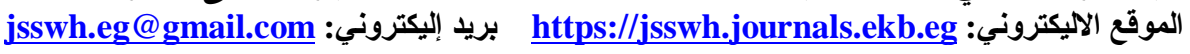

- مما يجعلنا نقبل الفرض الخامس للاراسة والأي مؤداه " توجد فروق جوهرية دالــة

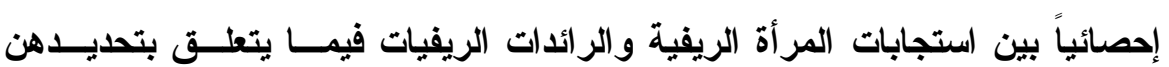
لمستوى تتمية الوعي لاى المرأة الريفية بمخاطر جائحة فيروس كورونا". تاسعا: تصور مقترح من منظور طريقة تنظيم المجتمع لتفعيل المسئولية الاجتماعية للرائدات الريفية بالوحدات الصحية وتنمية الوعى لاى المرأة الريفية بمخاطر جائحة فيروس كورونا:

أولا: الإطار العام للتصور المقترح: تفعيل المسئولية الاجتماعية للر ائدات الريفية بالوحدات الصحية لتتمية الوعى لدى المر أة الريفية بمخاطر جائحة فيروس كورونا" ثانيا: أهداف طريقة تنظيم المجتمع في تفعيل المسئولية الاجتماعية للر ائدات الريفية لتنمية الوعى لاى المرأة الريفية بمخاطر جائحة فيروس كورونا" 1 - أهداف تخطيطية : وذلك من خلال وضع خطة محددة للرائدات الريفية بالوحدات الصحية الريفية لمضمون المسئولية الاجتماعية وطبيعة ادوارهم في مواجهة الفيروسات وذلك من اجل تتمية الوعى لدى المرأة الريفية بمخاطر جائحة فيروس كورونا وذللك من خلص : أ) فهم الر ائدات الريفية بالوحدات الصحية الريفية لطبيعة دورهم .

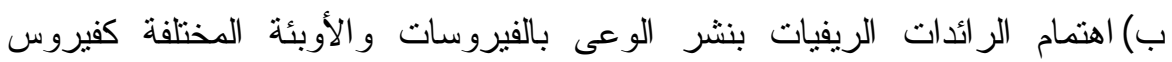

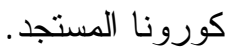
ج) حرص الرائدات الريفية على تكوين علاقات اجتماعية طيبة مع الأخرين من أجل خدمة المجتمع.

د) مشاركة الر ائدات الريفية في التصدي للمشكلات الصحية كجائحة فيروس كورونا ه) مسئولية الرائدات الريفية امام ذاتها في وقاية المترددات على الوحدات الصحية

$$
\text { الريفية من الفيروسات و المشكلات الصحية. }
$$

و ) حرص الر ائدات الريفيات على توعية المر أة الريفية بمخاطر الفيروسات و الأوبئة

$$
\text { مثل فيروس كورونا }
$$

ز) اهتمام الر ائدات الريفيات بتتمية معارفها في مجال عملها باستمرار . ح) تعاون الرائدات الريفيات مع فريق العمل في تتفيذ برامج التوعية الصحية. r - أهداف تثقيفية: من خلا قيام الرائدات الريفيات بتوعية وتتقيف المر أة

$$
\text { الريفية بمخاطر الفيروسات والأوبئة ( فيروس كورونا) . }
$$




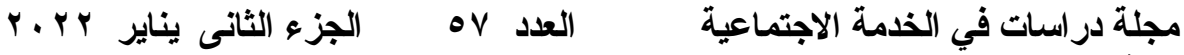

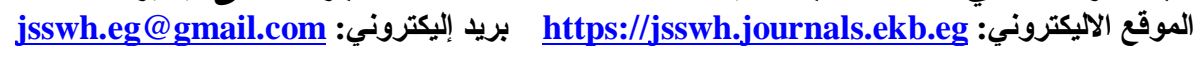

ثالثا: الاستراتيجيات التي يمكن استخدامها لتحقيق التصور المقترح :

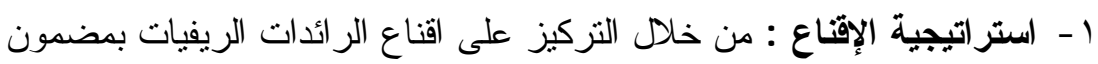

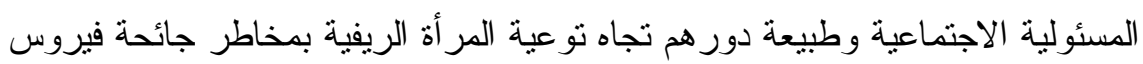

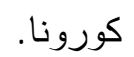
r - استراتيجية الاتصال : من خلال نسهيل عملية الاتصال بين الر ائدات الريفيات و المر أة

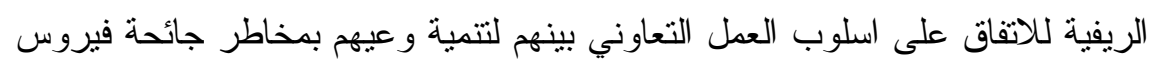
كورونا r - استراتيجية تغيير السلوك : من خلال الثأثثر على المرأة الريفية لتغيير الأفكار السلبية

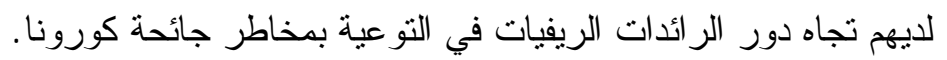

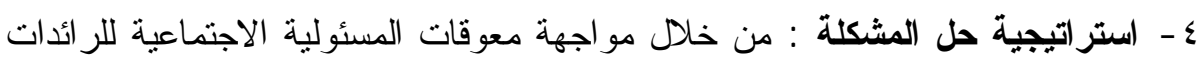

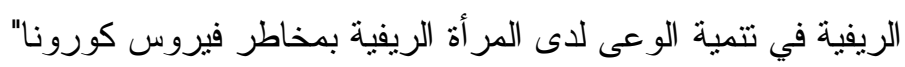
0 ـ - استراتيجية الضغط : من خلال الضغط على المسئولين الذين يبدون موقف اللامبالاة

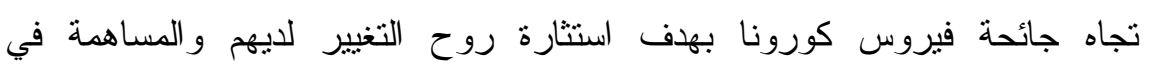
مو اجهنها.

رابعا: الأدوار التي يمكن أن يستخدها المنظم الاجتماعي لتحقيق التصور المقترح:

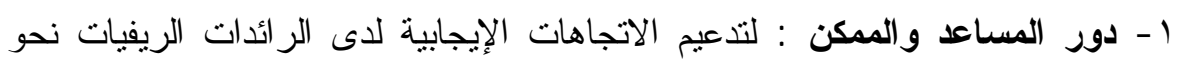

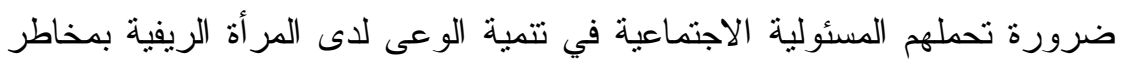

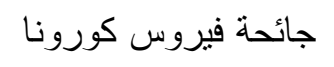

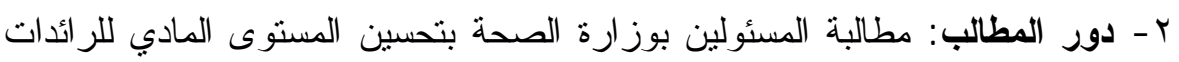

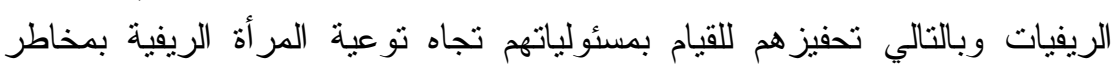
جائحة فيروس كورونا. r - الدور التربوي : العمل على تثقيف وتتمية وعى المر اءة الريفية بمخاطر جائحة

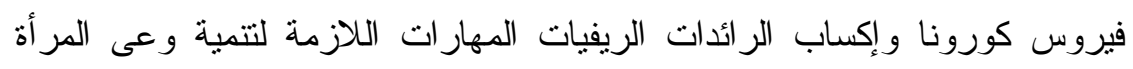
الريفية بمخاطر جائحة فيروس كورونا.

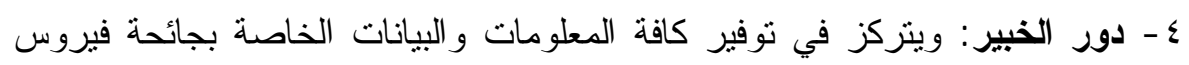

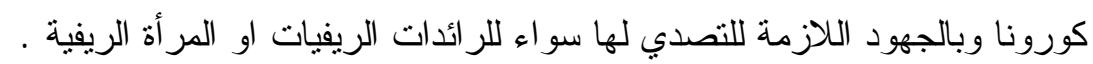
خامسا: المهارات التي يمكن أن يستخدمها المنظم الاجتماعي لتحقيق التصور المقترح: (مهار ات تتظيمية _ـمهارة الاتصال - مهارة حل المشكلة).

سادسا: الأدوات التي يمكن أن يستخدمها المنظم الاجتماعي لتحقيق التصور المقترح:

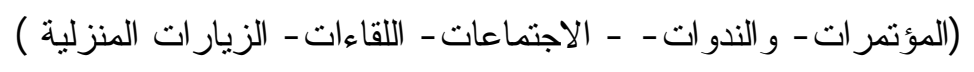




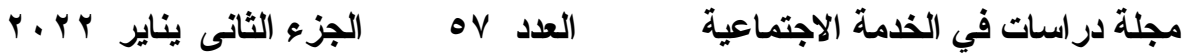

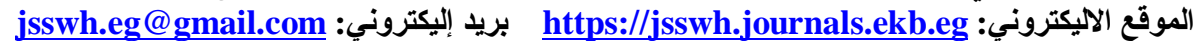

\section{أولاً : المراجع العربية : العزئ}

الاخيل ، عبد العزيز عبد الله (2006). معجم مصطلحات العلوم الاجتماعية ، عمان ، دار المناهج للنشر و التوزيع.

السيد , نجلاء رجب محمد (2020). شبكات التو اصل الاجتماعي وتتمية وعى المر أة بأزمة فيروس كورونا

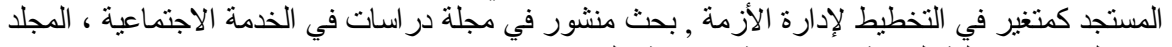

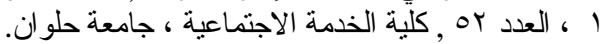

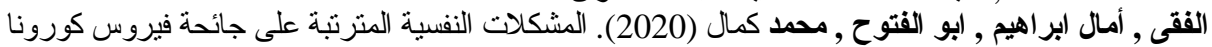

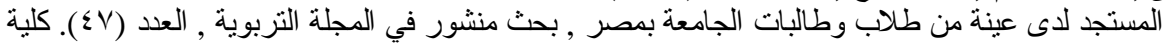

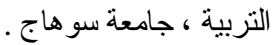
القاضي ، على عزت (1968) ـ جو انب مضيئة من المسئولية في الإسلام ، مجلة منبر الإسلام ، يصدرها

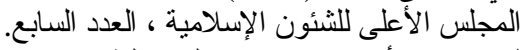

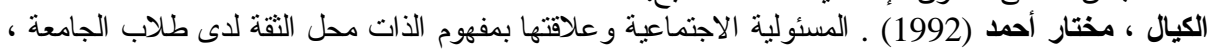

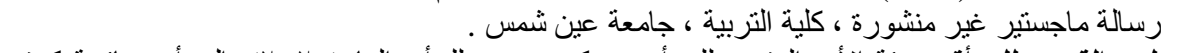

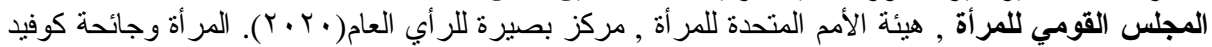

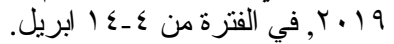

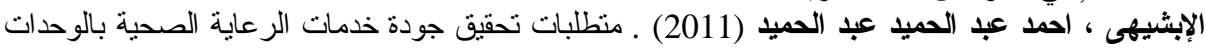

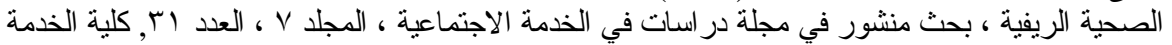

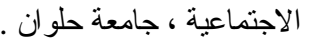

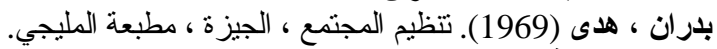

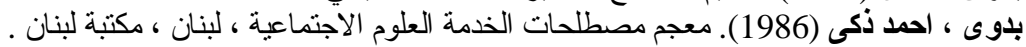

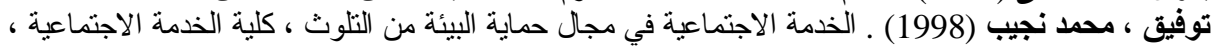

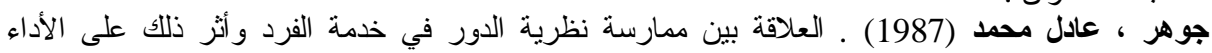

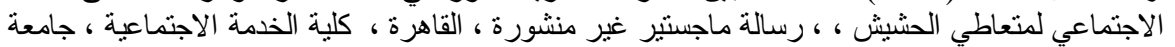
جمعية التنمية البيئية والصحية (2005). الحالة الصحية و الخدمات الصحية في مصر "در اسة تحليلية للوضع

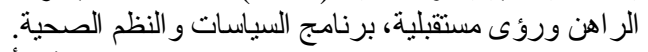

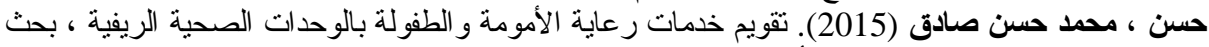

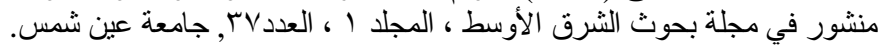

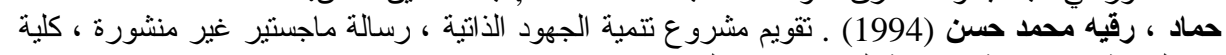

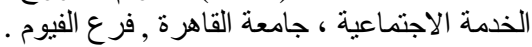

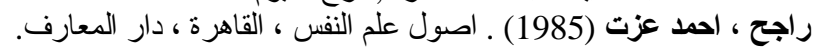

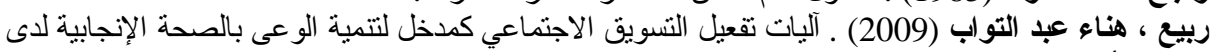

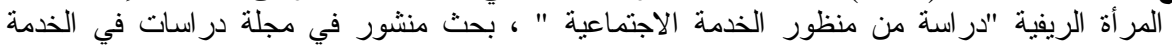

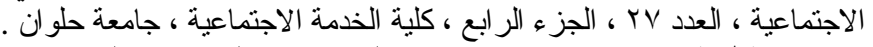

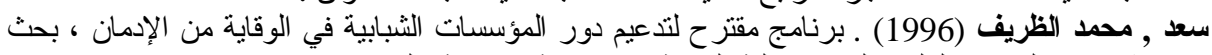

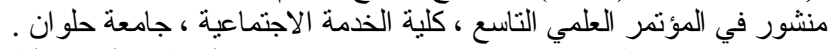

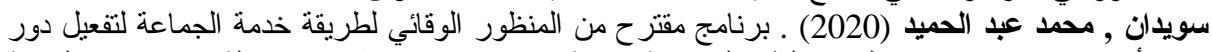

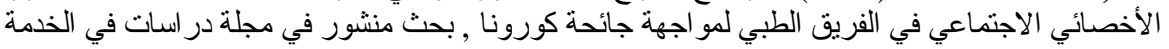

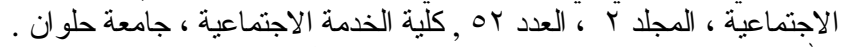

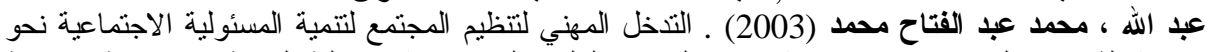
مشكلة إدمان المخدر ات ، بحث منشور في المؤتمر العلمي السادس عشر ، كلية الخدمة الاجتماعية ، جامعة الفية

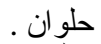

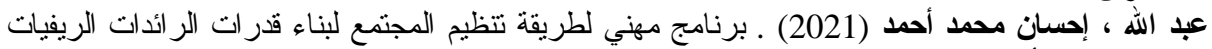

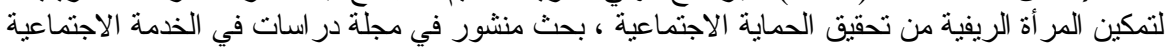

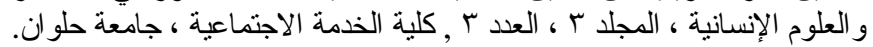

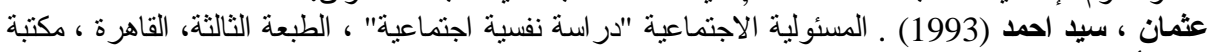
الأنجلو المصرية. قاسم، محمد رفعت (1990). تتظيم المجتمع "الأسس و الأجهزة" ، القاهرة ، دار الثقافة المصرية 
قنديل ، نجلاء يوسف (2009) ـ المعوقات التي نو اجه الر ائدات الريفيات في التوعية بمخاطر الممارسات

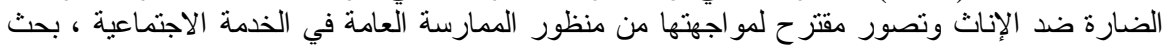

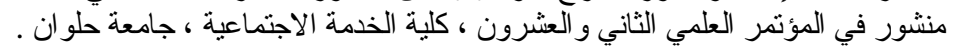

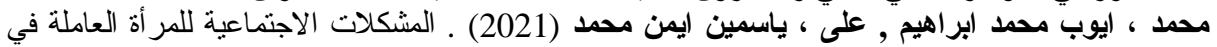

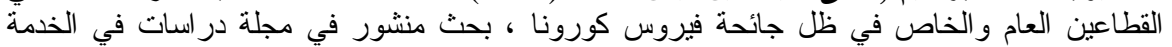

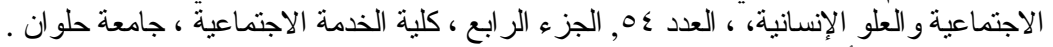

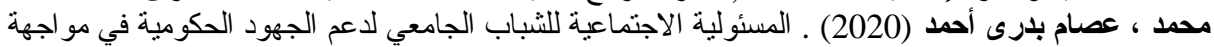

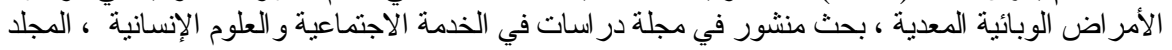

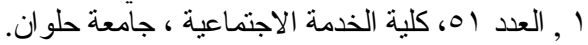

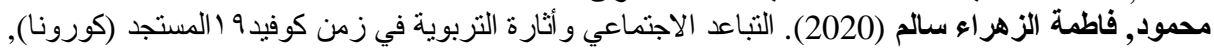

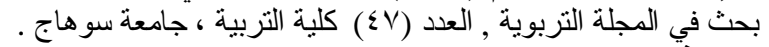

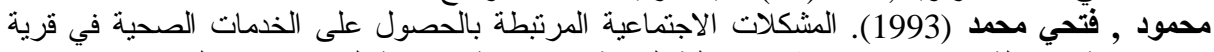

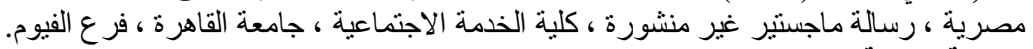

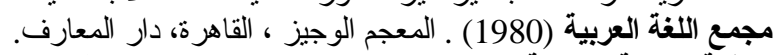

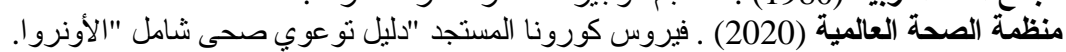

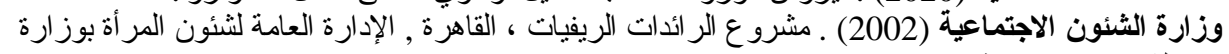

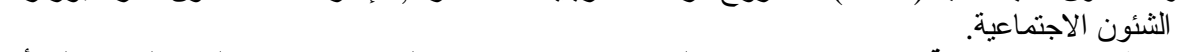
وزارة الشئون الاجتماعية (2002) ـ مشروع الرائدات الأدات الاجتماعيات ، القاهرة ، الإدارة العامة لشئون المرأة بوزارة الشئون الاجتماعية الاجئة ثانيا: المراجع الأجنبية:

Francis J. Turner (1986). Social work treatment, London, Macmillan press.

Fukuda,Sachiko (2000) . operationalizing Amara seen , s ideas on Capabilities , freedom and Human Rights, The shifting policy of human development approach.

Grossnikle D, Stephens. R (1992). Development personal and social responsibility, Macmillan new york .

Ian, Wallace (2007). Frame work for Revitalization or Rural Education and Educational Development

Irving, Sperge (1977). community problem solving, Encyclopedia of social welfare.

Joshi \& meenakshi (2004). Woman's empowerment Experience from watershed project, social welfare..

Mitev, D.(2019) . Corporative social responsibility as a factor to improve work motivation in hospital in Bulgaria, Troika journal of sciences, vol.17, supplies.

Mustrai, Shola\& Zebunnesa,Me he \& May, Rah man (may 2020). The effect of the corona virus from the lens of social science. See discussions, stats and author profiles for this publication at

http://www.researchgae.net/publication/34606981.

Stanton, Marietta (2009). Quality challenges in rural communities, online journal of rural nursing and health care, vol. 9, No. 1. 